\title{
Potestad sancionadora en materia de aguas y minas
}

\author{
Miguel Ángel González Iglesias ${ }^{1}$
}

Sumario: I. INTRODUCCIÓN. II. INFRACCIONES, SANCIONES, PRESCRIPCIÓN Y PROCEDIMIENTO ADMINISTRATIVO SANCIONADOR EN MATERIA DE AGUAS. 1. Infracciones. 2. Sanciones. 3. Prescripción de infracciones y sanciones. 4. Procedimiento administrativo sancionador. III. INFRACCIONES, SANCIONES, PRESCRIPCIÓN Y PROCEDIMIENTO ADMINISTRATIVO SANCIONADOR EN MATERIA DE MINAS. 1. Infracciones. 2. Sanciones. 3. Prescripción de infracciones y sanciones. D) Procedimiento administrativo sancionador.

\section{INTRODUCCIÓN}

Por todos es conocido el papel estelar que ha representado el dominio público para la formación de nuestra propia disciplina, al convertirse aquél en uno de los primeros títulos habilitantes que justificará la atribución de poderes de intervención a la Administración ${ }^{2}$. Así es, la Administración, en cuanto titular (dominio eminente), que no propietario, de los bienes de dominio público encontrará en la función de policía de los mismos uno de los pilares básicos sobre los que apoyarse y justificar las diversas potestades que aquélla va a ir articulando en torno a la regulación tanto de su uso como de su protección y conservación. En efecto, tal y como se ha escrito "el desarrollo de la potestad sancionadora de la Administración encontraría en la necesidad de proteger los bienes públicos uno de sus fundamentos más efectivos"3, presentando el contenido de dicha potestad sancionadora un rasgo peculiar pues, a través de ella, no sólo se persigue la represión del posible infractor sino la obtención de la reparación de los daños causados a los bienes públicos.

Pues bien, si ya desde los orígenes de nuestra disciplina se puso de manifiesto la necesidad de la existencia de una potestad sancionadora para reprimir-reparar las

1 Profesor Titular de Escuela Universitaria. Universidad de Salamanca.

2 Font i LLovet, T.: La protección del dominio público en la formación del Derecho administrativo español: Potestad sancionadora y resarcimiento de daños; RAP, núm. 123, septiembre-diciembre 1990 p. 79.

3 Font i LLovet, T.: La protección del dominio público en la formación del Derecho administrativo español: Potestad sancionadora y resarcimiento de daños; RAP, núm. 123, septiembre-diciembre 1990, p. 80. 
posibles conductas que atentaran contra la integridad de los bienes de dominio público, aquélla se justifica más aún en nuestros días debido al deterioro medioambiental que afecta, han sufrido y siguen sufriendo nuestros bienes de dominio público por los excesivos procesos de industrialización y, sobre todo, de urbanización ${ }^{4}$ que hemos venido y seguiremos soportando; lo que se ha traducido, por ejemplo, tanto en la contaminación y la pésima gestión de nuestros recursos hidráulicos, como en la defectuosa utilización de nuestros recursos mineros, debido a su mal uso y a su derroche excesivo. Todo ello, ha traído una mayor reglamentación en cada uno de los sectores afectados, en nuestro caso, aguas y minas, y ha conllevado, consecuentemente, a una mayor intervención administrativa5.

Así es, de entre las medidas de intervención con que cuenta la Administración para poder reprimir/reparar las posibles conductas infractoras que atenten contra la integridad de nuestros bienes de dominio público, se encuentra la potestad sancionadora ${ }^{6}$.

En este sentido, la potestad sancionadora de la Administración aparece constitucionalizada en el artículo 25, apartado 1, de nuestro Texto Fundamental7, al reco-

4 Así opina Palomar Olmeda, A.: La protección del Medio Ambiente en materia de aguas; RAP, núm. 110, mayo-agosto 1986, p. 108. Ver, también, en este sentido, Eugenio de Arcenegui, I.: La protección del medio ambiente a la luz de la legislación minera del Estado y de la Ley 12/81, de 24 de diciembre, de la Generalidad de Cataluña; RAP, núms. 101-102, vol. III, enero-diciembre 1983, pp. 2651 a 2689.

5 Como señala Guinot Barona, M. : "Cuando se trata de los bienes públicos es imprescindible facultar a la Administración a la que se le encomienda su tutela para que pueda ejercer esas funciones de policía con miras a la salvaguarda de los mismos, pues de otro modo, las genéricas declaraciones de protección contenidas en las leyes sectoriales que se ocupan del régimen jurídico de los diferentes bienes integrantes del demanio quedarían reducidas a meras declaraciones de intenciones carentes de auténtica

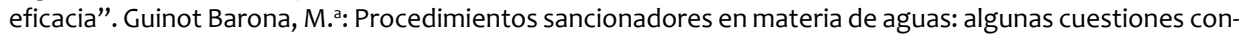
trovertidas; Actualidad Administrativa, La Ley 3737/2009, 6. ${ }^{\text {a }}$ Quincena del 16 al 31 de marzo de 2009, p. 1.

6 La doctrina denomina como sanciones de policía demanial a aquellas a través de las cuales la Administración protege sus pertenencias demaniales y, por ende, las funciones públicas que hacen de dichas pertenencias su soporte físico. En este sentido, cuando la sanción se impone al usuario del dominio público (vía concesión o autorización), estamos ante una sanción de tipo disciplinario pues se sustenta sobre una previa relación de sujeción especial. Ahora bien, la policía demanial también se aplica a quien con su actuación u omisión perturba o amenaza el buen orden de las cosas administrativas, aunque no esté en esa situación de una relación previa, revistiéndose en este caso la sanción un carácter más preventivo de protección de dichos bienes que disciplinario. En este sentido, ver García de Enterría, E., y Fernández, T.R.,

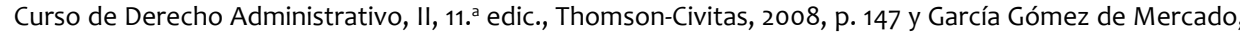
F.: Sanciones administrativas; garantías, derechos y recursos del presunto responsable, Comares, $2 .^{\mathrm{a}}$ edic, 2004, pp. 286 a 290.

$7 \quad$ La justificación de la existencia de la potestad sancionadora en manos de la Administración la encontramos, de forma clara, en la STC de 3 de octubre de 1983, cuando señala lo siguiente: "No cabe duda que en un sistema en que rigiera de manera estricta y sin fisuras la división de poderes del Estado, la potestad sancionadora debería constituir un monopolio judicial y no podría estar nunca en manos de la Administración, pero un sistema semejante no ha funcionado nunca históricamente y es lícito dudar que fuera incluso viable, por razones que no es ahora momento de exponer con detalle, entre las que se pueden citar la conveniencia de no recargar en exceso las actividades de la Administración de Justicia como consecuencia de ilícitos de gravedad menor, la conveniencia de dotar de una mayor eficacia el aparato represivo en 498 relación con ese tipo de ilícitos y la convecto de los hechos sancionados". 
nocerse que nadie puede ser sancionado por acciones $u$ omisiones que, en el momento de producirse, no constituyan infracción administrativa, según la legislación vigente, lo que viene a suponer la proclamación del principio de legalidad en materia sancionadora.

Como sabemos, tras la aprobación de la Constitución fueron el Tribunal Constitucional y nuestro Tribunal Supremo los que, a través de sus resoluciones, fueron creando una teoría general de las infracciones administrativas. Lo primero que dejaron claro en sus pronunciamientos ambos tribunales es que para el constituyente la sanción penal y la sanción administrativa reciben análoga consideración ${ }^{8}$. Así es, como recuerda la Sentencia del Tribunal Supremo de 28 de mayo de 1987, en su segundo considerando, “... tras la entrada en vigor de la Constitución en donde la sanción penal y la administrativa reciben la misma declaración del constituyente conforme al artículo 25 del Texto Fundamental (...) lo que hace que el Tribunal Constitucional, recordara en su Sentencia de 8 de junio de 1981, que los principios inspiradores del orden penal son de aplicación, con ciertos matices, al Derecho administrativo sancionador, dado que ambos son manifestaciones del ordenamiento punitivo del Estado tal como refleja la propia Constitución (art. 25 que consagra el principio de legalidad) y una muy reiterada jurisprudencia de este Tribunal Supremo ${ }^{9}$ de entre las que entresacamos las de 4 y 10 de noviembre de 1980 y las que en ellas se citan cuando insisten en que el acto u omisión castigados tienen que hallarse claramente definidos como faltas administrativas, siendo exigible la perfecta adecuación de las circunstancias objetivas determinantes de la ilicitud por una parte y las personales que a su vez determinan la imputabilidad...".

De este pronunciamiento, deducimos varios principios clave a los que habrá de sujetarse el ejercicio de la potestad sancionadora de la Administración.

En primer lugar, debe señalarse que si bien los principios del orden penal son de aplicación al ordenamiento administrativo sancionador, la Constitución no exige que se incorporen a este Derecho todos y cada uno de los principios propios y peculiares del orden penal. En efecto, si así fuera, la consecuencia más inmediata sería "que esa

8 Entre la doctrina, también recogen este planteamiento, por ejemplo, Martín-Retortillo Baquer, L.: Multas Administrativas; RAP, núm. 79, enero-abril, 1976, p. 16; Cano Mata, A.: Nuevo entorno de las infracciones y sanciones administrativas tras la entrada en vigor de la Constitución; REDA, núm. 56, octubrediciembre 1987, p. 573; Suay Rincón, J.: El Derecho administrativo sancionador: perspectivas de reforma, RAP, núm. 109, enero-abril 1986, pp. 211 a 214 y Díez-Picazo, L.M.a: Derecho Comunitario y medidas sancionadoras; REDA, núm. 78, abril-junio 1993, p. 264. De entre los que aceptan, en principio, este dogma de que la potestad sancionadora de la Administración forma parte, junto con la potestad penal de los Tribunales, de un ius puinendi superior del Estado, que además es único, de tal manera que aquéllas son sólo meras manifestaciones concretas de éste, pero con bastantes reticencias citaremos a Alejandro Nieto. Este autor señala las sombras de este dogma y denuncia la sustitución ilegítima que supone el que la potestad administrativa a quien realmente se quiere subordinar es a la actividad de los Tribunales penales y de que de donde se quiere nutrir al Derecho Administrativo Sancionador es del Derecho Penal y no del Derecho pú-

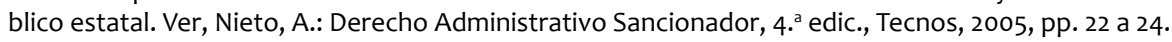

9 El Tribunal Supremo sigue haciéndose eco de esta doctrina constitucional en la actualidad como, por ejemplo, en su sentencia de 28 de julio de $1997, \mathrm{~F}^{\circ} \mathrm{D} .^{\circ} 4 .^{\circ}$ 
parte del derecho administrativo quedaría sin más integrada en el derecho penal, pues la única diferencia subsistente sería el "nombre jurídico" de la reacción (sanción frente a pena)" ${ }^{10}$. De esta manera, cuando se dice que las mismas garantías observables en la aplicación de las penas se han de respetar cuando se trata de imponer una sanción administrativa, a lo que en realidad se hace referencia es a la observancia de aquellos principios o garantías a los que el Derecho Penal debe someterse para satisfacer los postulados del Estado de Derecho, que son principios derivados de los declarados en la Constitución como fundamentales ${ }^{11}$. No obstante, de la declaración del Tribunal Constitucional se deducen dos límites clave en el ámbito sancionador, uno dirigido al legislador y otro a la Administración, en cuanto aplicadora del derecho sancionador concreto: el primero es que al legislador, por imperativo constitucional, le está prohibido el que incorpore a la regulación de las sanciones administrativas principios opuestos a los que rigen en el orden penal; el segundo es que la Administración, o los jueces en el supuesto caso de que se interponga el recurso, deberá en caso de laguna en el ámbito sancionador administrativo, acudir para colmar aquella a lo previsto en la Ley penal' ${ }^{12}$.

En segundo lugar, pues, habrá que preguntarse cuáles son esos principios o garantías fundamentales a los que el Derecho Administrativo sancionador debe someterse por influjo del Derecho Penal. Como señalamos antes estos principios o garantías fundamentales derivan directamente de la Constitución en tanto en cuanto no podemos olvidar que ambos, Derecho Administrativo Sancionador y Derecho Penal, han de satisfacer las exigencias y postulados del Estado de Derecho. Estos principios conocidos por todos, y derivados la mayoría del principio de legalidad, serían los siguientes: tipicidad de infracciones y sanciones administrativas, es decir, se requiere que el acto u omisión sancionados se hallen claramente definidos como falta o, dicho en otras palabras, que estén suficientemente reconocidos por la ley reconociendo describiendo con cuidado los elementos de la conducta, lo que obligará al legislador a realizar el máximo esfuerzo para que la seguridad jurídica quede salvaguardada en la definición de los tipos; culpabilidad y responsabilidad, o sea que, las infracciones administrativas, para ser merecedoras de sanción, deben ser culpables, atribuibles a su autor a título de dolo o culpa, correspondiendo a la Administración la averiguación de la identidad del presunto responsable o infractor de acuerdo con la legalidad vigente, para luego poder abrir contra él el oportuno procedimiento sancionadori3; el

10 Quintero Olivares, G.: La autotutela, los límites al poder sancionador de la Administración Pública y los principios inspiradores del Derecho penal; RAP, núm. 126, septiembre-diciembre 1991, p. 261.

11 Como señala Quintero Olivares, G.: “El procedimiento administrativo sancionador no está estructurado para dar cabida a momentos valorativos (procesos intelectivos, personalidad del individuo) cuya significación es primordial para el derecho penal. Y tampoco las autoridades administrativas podrían realizar una aplicación de normas que de facto y de iure requiriera razonamientos penales". Quintero Olivares, G.: La autotutela, los límites al poder sancionador de la Administración Pública y los principios inspiradores del Derecho penal; RAP, núm. 126, septiembre-diciembre 1991, p. 262.

12 Suay Rincón, J.: El Derecho administrativo sancionador: perspectivas de reforma, RAP, núm. 109, enero-abril 1986, pp. 213.

13 Junceda Moreno, J.: ¿Una vuelta hacia la responsabilidad objetiva en Derecho administrativo sancionador?; REDA, núm. 86, abril-junio, 1995, p. 265. 
principio de retroactividad de las disposiciones sancionadoras favorables ${ }^{14}$ y aplicación del principio de proporcionalidad entre las infracciones y las sanciones pertinentes ${ }^{15}$; la exclusión de la doble sanción por los mismos hechos (non bis in idem) ${ }^{16} \mathrm{y}$, por último, la prohibición de la interpretación extensiva y la aplicación analógica in peius de las normas sancionadoras ${ }^{17}$.

De otra parte, nuestra jurisprudencia ${ }^{18}$ ha venido a señalar, igualmente, que los principios esenciales reflejados en el artículo 24 de la Constitución, en materia de procedimiento, han de ser aplicables a la actividad sancionadora de la Administración, en la medida necesaria para preservar los valores esenciales que se encuentran en la base del precepto y la seguridad jurídica que garantiza el artículo 9 de la Constitución, porque la garantía del orden constitucional exige que el acuerdo se adopte a través de un procedimiento en el que el presunto inculpado tenga oportunidad de aportar y proponer pruebas y alegar a lo que su derecho convenga.

Ahora bien, el catálogo de derechos establecido en el artículo 24 de la Constitución, dirigidos a garantizar una tutela judicial efectiva de los intereses legítimos y derechos de las personas, no se agota con el mero respeto de las garantías allí enumeradas establecidas de forma evidente a favor del procesado. El artículo 24 de la Constitución incorpora, también, el interés público en un proceso justo, cuya relevancia constitucional no es posible desconocer, garantizado en el artículo 6 del Con-

14 En efecto, la STC de 30 de marzo de 1981 señala que "el artículo 9.3 de la Constitución garantiza la irretroactividad de las normas sancionadoras no favorables o restrictivas de derechos, dentro de cuya rúbrica han de entrar las administrativas sancionadoras, en las que declarar que la norma del artículo 9.3 ha de interpretarse también a contrario sensu, entendiendo que la Constitución garantiza la retroactividad de la Ley penal más favorable...".

15 Sobre el principio de proporcionalidad, ver el libro de Andrés Pérez, M. a del Rocío: El principio de proporcionalidad en el procedimiento administrativo sancionador; Bosch, 2008.

16 Como señala la STS de 19 de abril de 1999, F. $^{\circ}$ D. $.^{\circ} .^{\circ}, 3 .^{\circ}$ y $4 .^{\circ}:$ "Aunque el principio "non bis in idem" no se encuentra recogido expresamente en los artículos 14 a 30 de la Constitución, está íntimamente unido a los principios de legalidad y tipicidad de las infracciones, recogidos principalmente en el artículo 25 de la Constitución... Dicho principio impide que recaiga duplicidad de sanciones, administrativa y penal, en los casos en que se aprecie identidad de sujeto, hecho y fundamento del ius puniendi del Estado, sin la existencia de una relación de supremacía especial de la Administración que pudiera justificar el ejercicio de su potestad sancionadora con independencia de la punición penal... Entre las dos manifestaciones del ius puniendo estatal, potestad sancionadora de la Administración y ejercicio de la jurisdicción penal, se otorga prevalencia a la sentencia penal. Por una parte, desde el punto de vista procesal, puesto que, promovido un juicio criminal en averiguación de un delito o falta no puede seguirse pleito sobre el mismo hecho, suspendiéndose, si lo hubiera, en el estado en que se hallare hasta que recaiga sentencia firme en la causa criminal. Por otra parte, desde el punto de vista material, de manera que sancionado un ilícito como infracción penal por sentencia firme resulta claro el desapoderamiento de la Administración para sancionar por el mismo hecho... En caso de absolución en vía penal, cabe la sanción en vía administrativa cuando la tipificación en uno y otro ámbito resulten diferentes, al contemplar la protección de bienes jurídicos diversos; pero sí se produce condicionamiento en cuanto a los hechos que se declaran probados en la sentencia penal, pues unos mismos hechos no pueden existir y dejar de existir para los órganos del Estado".

17 Sobre esta cuestión ver Cano Campos, T.: La analogía en el Derecho administrativo sancionador; REDA, núm. 113, enero-marzo 2002, pp. 51 a 85.

18 Ver, en este sentido la STS de 16 de noviembre de $2001, \mathrm{~F}^{\circ} \mathrm{D} .^{\circ}{ }^{\circ} .^{\circ}$, que cita, entre otras, a la STC de 2 de junio de 1981. 
venio Europeo de Derechos Humanos, instrumento hermenéutico insoslayable para la interpretación de los derechos fundamentales de nuestra Constitución (artículo 10.2 de la Constitución), donde quedan intactas las garantías que asisten a todos sus partícipes y, especialmente, de quien se ve sometido al ejercicio del "ius puniendi" del Estado.

Así pues, aplicando la anterior doctrina toda persona que mantenga una determinada relación jurídica con la Administración Pública, que haya sido objeto de sanción administrativa, cuyo ejercicio participa de los principios, con ciertos matices, del Derecho Penal, necesariamente tiene derecho al recurso administrativo o jurisdiccional correspondiente para revisar la legalidad de la sanción impuesta.

Pues bien, puede decirse sin temor a equivocarnos que la casi totalidad de las leyes administrativas sectoriales surgidas con posterioridad a la Constitución contienen o contemplan, en su estructura, algún título o algún capítulo dedicado a la potestad sancionadora, como sucede con el TRLA ${ }^{19}$ y con la $L M i^{20}$ si bien esa regulación deja mucho que desear en cuanto al método, al rigor y a la técnica propia del Derecho Penal ${ }^{21}$.

En efecto, si bien puede decirse que la inmensa mayoría de los principios que rigen hoy la potestad sancionadora de las Administraciones Públicas y que han ido confirmándose por la jurisprudencia constitucional han sido positivizados en la Ley 30/1992, de 26 de noviembre, de Régimen Jurídico de las Administraciones Públicas y del Procedimiento Administrativo Común (en adelante, LRJPAC) y por el Reglamento para el ejercicio de la potestad sancionadora, aprobado por Real Decreto 1398/1993, de 4 de agosto (en adelante, RPS), lo cierto es que aquélla no regula de forma completa un procedimiento sancionador, a diferencia de la Ley de Procedimiento del año $1958^{22}$, sino que se limita a prever una serie de principios básicos, en su Título IX, a los

19 En efecto, es el Título VII del TRLA, que lleva por rúbrica: “De las infracciones y sanciones y de la competencia de los tribunales", el que regula en el ámbito estatal el ejercicio de la potestad sancionadora en materia de aguas.

20 En esta norma, es el Título XIII de la LMi, denominado: “Competencia administrativa y sanciones”, el destinado a la regulación del ejercicio de la potestad sancionadora en materia de minas en el ámbito estatal.

21 Beltrán Aguirre, J.L.: La prescripción de las infracciones administrativas: Unificación de la doctrina jurisprudencial; REDA, núm. 73, enero-marzo 1992, p. 111. De ahí que la afirmación de García de Enterría cuando señalaba que "el capítulo de la actividad sancionadora de la Administración es de los más imperfectos en nuestro actual Derecho público” siga de plena actualidad. Así se expresaba en García de Enterría, E.: El problema jurídico de las sanciones administrativas, REDA, núm. 10, 1976, p. 430.

22 En contra de este sistema de regulación de la potestad sancionadora de nuestras Administraciones Públicas, se muestran abiertamente tanto González Navarro, F., cuando señala que: “O sea, que lo que se proponen los autores de la LRJPA es sustituir un procedimiento administrativo común por una multiplicidad indeterminada de procedimientos... Esto es un error de tal calibre que cuesta trabajo creerIo", en: El "Big-Bang" del procedimiento administrativo sancionador común; REDA, núm. 78, abril-junio 1993, p. 225; como Pemán Gavín, J. al expresar que: “Uno de los efectos importantes que en relación con la materia sancionadora ha tenido la entrada en vigor de la LRJAP ha sido la derogación del procedimiento sancionador regulado en los artículos 133 a 137 de la LPA, procedimiento sancionador que, como es bien 
que deberán someterse el resto de procedimientos sancionadores, tantos cuantas sean las manifestaciones de la potestad sancionadora ${ }^{23}$.

Teniendo esto presente, entonces, debemos preguntarnos cuál es el régimen jurídico que en materia de potestad sancionadora, en el ámbito estatal, es aplicable a las aguas y a las minas y que va encaminado, a través del ejercicio de la potestad de policía, a la protección de dichos bienes de dominio público ${ }^{24}$ por la Administración competente para ello. Dicho régimen se caracteriza, en la actualidad, por su complejidad y por su dispersión normativa, lo que dificulta su tratamiento, en una materia tan sensible para los ciudadanos como es esta de la potestad sancionadora.

Ciertamente, la complejidad deriva porque dicho régimen se contiene no sólo en la normas de referencia sino en una multiplicidad de normas, que regulan otras materias (residuos, responsabilidad medioambiental, evaluación de impacto ambiental, etc.) pero que afectan a las aguas y a las minas, en cuanto que recursos naturales que son, al contener algunas disposiciones que hacen referencia a la potestad sancionadora.

sabido, venía cumpliendo una importante función de suplencia en todos aquellos ámbitos sancionadores en los que la legislación sectorial no establece una regulación del procedimiento sancionador... Esta opción derogatoria resulta sin duda una opción discutible porque no se alcanza a apreciar la incompatibilidad existente entre los principios y reglas procedimentales incorporados a la LRJAP y el iter procedimental diseñado por la Ley de 1958, iter procedimental ciertamente esquemático, pero que en nada perjudica a las regulaciones procedimentales más detalladas establecidas tanto por el propio Estado como por las Comunidades Autónomas y que, por otra parte, no hubiera sido difícil integrar con los criterios plasmados en los arts. 134 a 138 LRJAP”. Así lo expone en: La regulación de la potestad sancionadora de la Administración en la Ley 30/1992, de 26 de noviembre: notas sobre su tramitación parlamentaria; RAP; núm. 132, septiembrediciembre 1993, p. 411.

23 En torno a la ausencia de una teoría general del ilícito administrativo, reflexiona Gómez Tomillo que: “La falta de una teoría general del ilícito administrativo, ..., quizá se encuentre en la base de la ausencia de una auténtica parte general de la infracción administrativa análoga a la desarrollada en otros países de nuestro entorno jurídico o cultural. Las disposiciones contenidas en el Título IX de la LRJ-PAC, si bien consiguieron un avance en relación con la situación precedente, no proporcionan un cuadro suficientemente satisfactorio y completo. Son múltiples las lagunas que se detectan en la citada Ley, algunas de las cuales han sido denunciadas por la doctrina y que van desde la punición de las infracciones culposas, al régimen de la comisión por omisión, pasando por las causas de justificación, la inimputabilidad, cuestiones conexas con el error, la tentativa, la multiplicidad de intervinientes o los casos de pluralidad de infracciones, entre otras. Se trata de problemas, todos ellos, no resueltos satisfactoriamente en los artículos 127 a 138 de la LRJ-PAC que sólo secundariamente se ocupa de los mismos". Gómez Tomillo, M.: Derecho Administrativo Sancionador. Parte General. Teoría General y Práctica del Derecho Penal Administrativo, Thomson-Aranzadi, 2008, p. 26. También critica la pasividad del legislador en esta materia y, por lo tanto, la ausencia en España de una Ley General de las Infracciones y Sanciones Administrativas, lo que no se entiende bien habida cuenta de los materiales con que el legislador ya tiene: doctrinales, jurisprudenciales y de De-

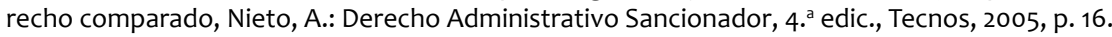

24 De conformidad con el art. 1.3 del Real Decreto Legislativo 1/2001, de 20 de julio, por el que se aprueba el Texto Refundido de la Ley de Aguas (en adelante, TRLA): Las aguas continentales superficiales, así como las subterráneas renovables, integradas todas ellas en el ciclo hidrológico, constituyen un recurso unitario, subordinado al interés general, que forma parte del dominio público estatal como dominio público hidráulico".

Y, según el art. 2.1 de la Ley 22/1973, de 21 de julio, de Minas (en adelante, LM): Todos los yacimientos de origen natural y los demás recursos geológicos existentes en el territorio nacional, mar territorial y plataforma continental, son bienes de dominio público, cuya investigación y aprovechamiento el Estado podrá asumir directamente o ceder en la forma y condiciones que se establecen en la presente Ley". 
Y, derivado e inexorablemente unido a lo anterior, estamos ante un régimen disperso porque no se agota la regulación del ejercicio de la potestad sancionadora, a nivel estatal, con la referencia a las normas generales (aguas y minas), pues hay que tener en consideración también las disposiciones que en lo relativo al régimen sancionador se prevén tanto en la Ley 10/1998, de 21 de abril, de Residuos ${ }^{25}$, como en la Ley 26/2007, de 23 de octubre, de Responsabilidad Medioambiental ${ }^{26} \mathrm{y}$, también, el actual Real Decreto Legislativo 1/2008, de 11 de enero, que aprueba el Texto Refundido de las disposiciones legales vigentes en materia de Evaluación de Impacto Ambiental de proyectos ${ }^{27}$. Nosotros, por razones obvias de espacio nos centraremos exclusivamente en el régimen estatal contenido en las leyes especiales que contienen la regulación del ejercicio de la potestad sancionadora para este tipo de bienes: aguas y minas y sus disposiciones de desarrollo.

De esta manera y por lo que respecta a la materia de aguas, hay que decir que el marco jurídico estatal, que regula el ejercicio de la potestad de policía para la protección y conservación del dominio público hidráulico del Estado, se contiene, en primer lugar, tanto en el Título VII del TRLA (artículos 116 a 121 bis), que lleva por rúbrica: “De las infracciones y sanciones y de la competencia de los Tribunales", y que uniforma toda la legislación del Estado en materia de aguas en cuanto al ejercicio de la potestad sancionadora como, a nivel reglamentario, a su normativa de desarrollo, es decir, habrá que estar a lo dispuesto en el Capítulo I del Título V del Reglamento de Dominio Público Hidráulico, aprobado por Real Decreto 849/1986, de 11 de abril28 (en adelante, $\mathrm{RDPH})$. Además, supletoriamente le será de aplicación la normativa prevista en la Ley de Patrimonio de las Administraciones Públicas (LPAAPP) en materia de infracciones

25 La LR regula la responsabilidad administrativa derivada del incumplimiento de lo previsto en la misma en el Capítulo II del Título VI (arts. 32 a 38), tipificando tanto las conductas que constituyen infracción como las sanciones que procede imponer a consecuencia de ello.

26 Es el Capítulo V de la LRM (arts. 35 a 40) el que se ocupa del régimen de las infracciones y sanciones. Pues bien, a diferencia de lo que ocurre en el régimen de responsabilidad medioambiental, donde el concepto de operador engloba tanto a personas privadas como a públicas, el régimen sancionador de esta Ley sólo prevé la imposición de sanciones a personas físicas y jurídicas privadas. En este sentido, las infracciones tipificadas en su art. 37 definen aquellos comportamientos que constituyen incumplimientos de las obligaciones que la LRM impone a los operadores, agrupándolas en dos categorías, muy graves y graves, atendiendo a los perjuicios, mayores o menores, que para los recursos naturales puedan derivarse de tales conductas. Las sanciones, por su parte, prevén multas que oscilan entre los 50,001 y los 2.000.000 de euros, en el caso de infracción muy grave, y entre los 10.001 y los 50.000 euros, en el caso de las infracciones graves. Además, se prevé en ambos casos la posibilidad de suspender la autorización concedida al operador por un periodo máximo de dos años en las infracciones muy graves y de uno en el caso de las infracciones graves. Por su lado, el Capítulo VI (arts. 41 a 49) regula algunas disposiciones de naturaleza procedimental (la LRM no puede regular el procedimiento en esta materia al ser competencia de las Comunidades Autónomas) tales como las formas de iniciación; la adopción de las medidas provisionales oportunas; el contenido básico de la resolución del procedimiento; los medios de ejecución forzosa, etc.

27 Su Capítulo III, en los arts. 20 y 21 tipifica las infracciones y sanciones correspondientes, cerrando su regulación con las cuestiones referentes a la suspensión de la ejecución del proyecto o actividad por omisión o defectos en la evaluación de impacto ambiental (art. 22) y con la reparación e indemnización de daños (art.23). Dentro de los proyectos que, en todo caso, han de someterse a evaluación de impacto ambiental (art. 3 y anexo I) se encuentran los del Grupo 1: Agricultura, silvicultura, acuicultura y ganadería; los del Grupo 2: Industria extractiva y Grupo 9: Otros proyectos.

28 Modificado por el Real Decreto 606/2003, de 23 de mayo. 
y sanciones. En segundo lugar, a lo dispuesto en el Título IX de la LRJPAC ${ }^{29}$ y en el Real Decreto 1398/1993, de 4 de agosto, por el que se aprueba el Reglamento del Procedimiento para el Ejercicio de la Potestad Sancionadora (RPES, en adelante). En tercer y último lugar, a lo previsto en el Derecho penal.

En lo que respecta a las minas, habrá que estarse, por lo que respecta a la potestad sancionadora, a lo dispuesto en primer lugar, tal y como señala el artículo 114.1 a las disposiciones que contiene la propia LM (contenidas en el Título XIII: artículos 114 a 122) y sus disposiciones de desarrollo: es decir, el Real Decreto 2857/1978, de 25 de agosto, por el que se aprueba el Reglamento General para el Régimen de la Minería (RGRM) con carácter fundamental ${ }^{30}$. En segundo lugar a lo previsto por las restantes normas de derecho administrativo; es decir LPAAPP, la LRJPAC ${ }^{31}$ y el RPES. Y, en su defecto, por las normas de Derecho privado que les resulten aplicables. No obstante, habrá que entender que será el Derecho penal, tal y como han señalado la doctrina y la jurisprudencia, al que habrá de considerarlo como el auténtico derecho supletorio de segundo grado.

Pasemos, pues, sin más dilación a ver las peculiaridades propias del ejercicio de la potestad sancionadora que, en el ámbito estatal, se lleva a cabo en materia de aguas y minas.

\section{INFRACCIONES, SANCIONES, PRESCRIPCIÓN Y PROCEDIMIENTO ADMINISTRATIVO SANCIONADOR EN MATERIA DE AGUAS}

\section{Infracciones}

Hay que comenzar señalando que si bien el régimen general sancionador en la materia, por lo que se refiere al dominio público estatal, viene previsto en los artícu-

29 No se acaban aquí las referencias a normas que, con carácter estatal, contienen un régimen sancionador aplicable a la materia de aguas, pues habría que tener en consideración también las disposiciones que en lo relativo al régimen sancionador se prevén tanto en la Ley 10/1998, de 21 de abril, de Residuos, como en la Ley 26/2007, de 23 de octubre, de Responsabilidad Medioambiental.

30 No obstante, no acaba aquí todo lo relacionado con la potestad sancionadora en materia minera pues habría que tener en cuenta, además, toda una serie de Reglamentos aprobados sobre minería que prevén disposiciones en materia de potestad sancionadora, como son: el Real Decreto 863/1985, de 2 de abril, por el que se aprueba el Reglamento General de normas básicas de seguridad minera, que en su Capitulo XV (art. 169) prevé el capítulo dedicado a las sanciones; el Real Decreto 2994/1982, de 15 de octubre, sobre restauración del espacio mineral afectado por actividades mineras, cuyo art. 7 señala que el incumplimiento del Plan de restauración conllevará la aplicación de las sanciones previstas en la legislación de minas, pudiendo acordarse la caducidad de la concesión de explotación o permiso de investigación, en caso de incumplimiento, de acuerdo con lo previsto en dicha legislación; y, por último, el Real Decreto 975/2009, de 12 de junio, sobre gestión de los residuos de las industrias extractivas y de protección y rehabilitación del espacio afectado por actividades mineras, cuyo Título IV (art. 46) contempla el régimen sancionador previsto en caso de que el mismo se incumpla.

31 No se acaban aquí, al igual que sucede en materia de aguas, las referencias a las normas que, con carácter estatal, contienen un régimen sancionador aplicable a la materia de minas, pues habría que tener en consideración también las disposiciones que en lo relativo al régimen sancionador se prevén tanto en la Ley 10/1998, de 21 de abril, de Residuos, como en la Ley 26/2007, de 23 de octubre, de Responsabilidad Medioambiental. 
los 192 y siguientes de la Ley 33/2003, de 3 de noviembre, de Patrimonio de las Administraciones Públicas, no obstante, hay regímenes especiales en las distintas leyes que regulan los bienes que se integran en ese dominio, prevaleciendo, por lo tanto dicho régimen especial respecto del contenido en la norma general ${ }^{32}$.

En efecto, y en este sentido, el TRLA dispone el catálogo de infracciones administrativas en materia de dominio público hidráulico, remitiéndose a la norma reglamentaria de desarrollo para efectuar su clasificación.

En efecto, cumpliendo con los principios de legalidad ${ }^{33}$ y tipicidad, básicos en materia sancionadora, el TRLA realiza una regulación pormenorizada de lo que son las infracciones en materia de aguas, tipificando como tales a las siguientes ${ }^{34}$ :

32 Así es, como señala la Exposición de Motivos de la Ley del Patrimonio de las Administraciones Públicas, “En todo caso, la regulación de los bienes y derechos de dominio público ... está pensada para operar con carácter supletorio respecto de la legislación especial. La aplicación en primer grado de sus normas se producirá, por tanto, sólo en relación con aquellos bienes demaniales por afectación que carecen de una disciplina específica". Evidentemente, no es el caso de las aguas y de las minas que cuentan con su propia legislación especial.

En este sentido, también se manifiesta García Gómez de Mercado, F.: Sanciones Administrativas:

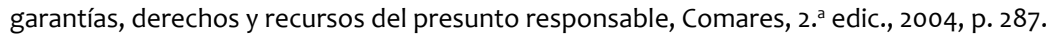

33 Como señala la STC de 3 de octubre de 1983, el art. 25.1 CE exige "la necesaria cobertura de la potestad sancionadora en una norma de rango legal, habida cuenta del carácter excepcional que los poderes sancionatorios en manos de la Administración presentan". En consecuencia, la potestad sancionadora de la Administración, para ajustarse a la legalidad y a nuestra Constitución ha de estar habilitada en una norma de rango legal. Ahora bien, como señala Mestre Delgado, J.F.: “... esta declaración genérica debe ser objeto de las necesarias matizaciones, a fin de conocer el verdadero contenido del principio de legalidad en materia sancionadora". En este sentido, continúa reflexionando el autor citado, "salvando los supuestos de relaciones de sujeción especial, el principio de reserva de ley se ve respetado incluso por la existencia de remisiones a normas reglamentarias", siempre que esa regulación reglamentaria esté claramente subordinada a la Ley, no permitiéndose, en absoluto, las remisiones genéricas y las habilitaciones en blanco al Ejecutivo. No se exige que los reglamentos sean única y exclusivamente una mera reproducción de los preceptos de la Ley, ya que los preceptos reglamentarios implican un novum mayor o menor. En este sentido, la única figura normativa con la que la Administración puede desarrollar su potestad sancionadora es la del Reglamento ejecutivo. En resumen, los contenidos esenciales del régimen sancionador han de estar contenidos en una Ley formal. Además, en materia sancionadora, la previa habilitación legal al reglamento exige que se concreten los principios que van a ser objeto de desarrollo, tanto en lo que se refiere a la tipificación de las conductas que se consideren infracción como al establecimiento y gradación de las sanciones. En definitiva, el art. 25.1 CE obliga al legislador a regular por sí mismo los tipos de infracción administrativa y las sanciones correspondientes, en la medida necesaria para dar cumplimiento a la reserva de ley.

Sobre esta misma cuestión la STS de 21 de diciembre de 2001 señala que el principio de reserva de ley en materia sancionadora, permite alguna concesión al reglamento, pero con la condición de que no se trate de una regulación independiente, sino claramente subordinada a las previsiones del legislador $\left(\right.$ F.D. $\left.{ }^{\circ} .^{\circ}\right)$.

Sobre estas reflexiones ver Mestre Delgado, J.F.: Potestad reglamentaria y principio de legalidad: las limitaciones constitucionales en materia sancionadora; REDA, núm. 57, enero-marzo 1988, pp. 79 a 88 y Esteve Pardo, J.: Sanciones Administrativas y potestad reglamentaria; REDA, núm. 49, enero-marzo, 1986, pp. 99 a 108.

34 Ver art. 116.3 del TRLA. Modificado por Ley 25/2009, de 22 de diciembre, de modificación de diversas leyes para su adaptación a la Ley sobre el libre acceso a las actividades de servicios y su ejercicio que añade las letras i) y j) a su contenido. 
a) Las acciones que causen daños a los bienes de dominio público hidráulico y a las obras hidráulicas.

b) La derivación de agua de sus cauces y el alumbramiento de aguas subterráneas sin la correspondiente concesión o autorización cuando sea precisa.

c) El incumplimiento de las condiciones impuestas en las concesiones y autorizaciones administrativas a que se refiere esta Ley, sin perjuicio de su caducidad, revocación o suspensión.

d) La ejecución, sin la debida autorización administrativa, de otras obras, trabajos, siembras o plantaciones en los cauces públicos o en las zonas sujetas legalmente a algún tipo de limitación en su destino o uso.

e) La invasión, la ocupación o la extracción de áridos de los cauces, sin la correspondiente autorización.

f) Los vertidos que puedan deteriorar la calidad del agua o las condiciones de desagüe del cauce receptor, efectuados sin contar con la autorización correspondiente.

g) El incumplimiento de las prohibiciones establecidas en la presente Ley o la omisión de los actos a que obliga; y, por último,

h) La apertura de pozos y la instalación en los mismos de instrumentos para la extracción de aguas subterráneas sin disponer previamente de concesión o autorización del organismo de cuenca para la extracción de las aguas.

i) La no presentación de declaración responsable o el incumplimiento de las previsiones contenidas en la declaración responsable para el ejercicio de una determinada actividad o de las condiciones impuestas por la Administración para el ejercicio de la misma.

j) La inexactitud, falsedad u omisión en los datos, manifestaciones o documentos que se incorporen o acompañen a la declaración responsable.

Como señala Suárez Ferrín: “coinciden las infracciones con las tipificadas en la Ley 33/2003, de 3 de noviembre, del Patrimonio de las Administraciones Públicas en cuanto a los daños causados al dominio público, o la utilización sin concesión o autorización o excediendo los límites y condiciones de las mismas". Suárez Ferrín, M. a A.: Infracciones y Sanciones; Capítulo I del Libro dirigido por De Fuentes Bardají, J.: Comentarios a la Ley de Patrimonio de las Administraciones Públicas; Abogacía General del Estado (Ministerio de Justicia) y Thomson-Aranzadi, 2008, p. 1327. 
Pues bien, de conformidad con el TRLA ${ }^{35}$ estas infracciones han de calificarse reglamentariamente en leves, menos graves, graves y muy graves, en atención a:

— Su repercusión en el orden y aprovechamiento del dominio público hidráulico.

— Su trascendencia por lo que respecta a la seguridad de las personas y bienes.

- Las circunstancias del responsable, su grado de malicia, participación y beneficio obtenido; $y$, por último,

— El deterioro producido en la calidad del recurso.

En consecuencia, la clasificación de las infracciones ha de obtenerse, en todo lo que no se oponga al vigente TRLA, del RDPH. De conformidad con el mismo ${ }^{36}$, las siguientes infracciones tendrán la consideración y se clasifican en:

\section{Leves 37 :}

- Las acciones u omisiones que causen daños a los bienes de dominio público hidráulico, siempre que la valoración de aquéllos no supere los 450,76 euros ${ }^{38}$.

- El incumplimiento de las condiciones impuestas en las concesiones y autorizaciones administrativas a que se refiere la Ley de Aguas en los supuestos en que no dieran lugar a caducidad o revocación de las mismas.

- La ejecución sin la debida autorización administrativa de obras, trabajos, siembras o plantaciones en los cauces públicos o en las zonas sujetas legalmente a algún tipo de limitación en su uso, en los supuestos en que no se derivaran de tales actuaciones daños para el dominio público hidráulico o, de producirse, su valoración no superara los 450,76 euros.

- La invasión o la ocupación de los cauces o la extracción de áridos en los mismos, sin la correspondiente autorización, cuando no se derivaran daños para el dominio público hidráulico o de producirse éstos la valoración no superara los 450,76 euros.

- El daño a las obras hidráulicas o plantaciones y la sustracción y daños a los materiales acopiados para su construcción, conservación, limpieza y monda en los

35 Art. 117.1 TRLA.

36 Ver Arts. 314 a 317 RDPH.

37 Art. 315 RDPH.

38 La Resolución de 21 de noviembre de 2001, de la Subsecretaría del Ministerio de Medio Ambien-

508 te, convirtió a euros las cuantías de este artículo. 
supuestos en que la valoración de tales daños, o de lo sustraído, no superara los 450,76 euros.

- El corte de árboles, ramas, raíces o arbustos en los cauces, riberas o márgenes sometidos a régimen de policía sin autorización administrativa.

- La navegación sin autorización legal.

- El cruce de canales o cauces, en sitio no autorizado, por personas, ganado o vehículos.

- La desobediencia a las órdenes o requerimiento de los funcionarios de los servicios del Organismo de cuenca en el ejercicio de las funciones que tiene conferidas por la legislación vigente; $y$, para terminar;

- El incumplimiento de cualquier prohibición establecida en la Ley de Aguas y en el presente Reglamento o la omisión de los actos a que obligan, siempre que no estén consideradas como infracciones menos graves, graves o muy graves.

Menos graves ${ }^{39}$ :

- Las acciones u omisiones que causen daños a los bienes del dominio publico hidráulico, siempre que la valoración de aquéllos esté comprendida entre 450,77 y $4.507,59$ euros.

- El incumplimiento de las condiciones impuestas en las concesiones y autorizaciones administrativas en los supuestos en que hubiera lugar a la declaración de caducidad o revocación de las mismas.

- La derivación de aguas de sus cauces y el alumbramiento de aguas subterráneas sin la correspondiente concesión o autorización cuando sea precisa, así como la realización de trabajos o mantenimiento de cualquier medio que hagan presumir la continuación de la captación abusiva de las mismas, siempre que, en estos últimos supuestos, exista requerimiento previo del Organismo de cuenca en contrario.

- La ejecución, sin la debida autorización administrativa, de obras, trabajos, siembras o plantaciones en los cauces públicos o en las zonas sujetas legalmente a algún tipo de limitación en su uso, en los supuestos en que, de producirse daños para el dominio público hidráulico, su valoración estuviera comprendida entre 450,77 y $4 \cdot 507,59$ euros.

39 Art. $316 \mathrm{RDPH}$. 
- La invasión o la ocupación de los cauces o la extracción de áridos en los mismos sin la correspondiente autorización, cuando se produjeran como consecuencia de ello daños para el dominio público cuya valoración estuviera comprendida entre 450,77 y $4.507,59$ euros.

- Los daños a las obras hidráulicas o plantaciones y la sustracción o daños a los materiales acopiados para su construcción, conservación, limpieza y monda, en los supuestos en que la valoración de tales daños o de los bienes sustraídos estuviera comprendida entre 450,77 y 4.507,59 euros.

- Los vertidos que puedan deteriorar la calidad del agua o las condiciones de desagüe del cauce receptor, efectuados sin contar con la autorización correspondiente y siempre que los daños derivados para el dominio público no fueran superiores a $4.507,59$ euros.

\section{Graves o muy graves ${ }^{40}$ :}

- Cualquiera de las infracciones enumeradas en los artículos anteriores cuando de los actos y omisiones en ellos previstos se deriven para el dominio público hidráulico daños cuya valoración supere los 4.507,59 euros y los 45.075,91 euros, respectivamente.

Por otra parte, respecto a quién o quiénes puedan ser los posibles responsables de la comisión de estas infracciones el TRLA sólo menciona que "la responsabilidad será solidaria cuando sean varios los responsables y no sea posible determinar el grado de participación de cada uno de ellos en la comisión de la infracción" pero no especifica nada más acerca de la posible autoría de los hechos o de las omisiones infractoras. $\mathrm{Y}$, de igual forma, tampoco se hace alusión a ellos en la LPAP, razón por la que habrá que estarse a lo previsto en la LRJPAC en esta concreta cuestión.

En este sentido, el art. 130 LRJPAC, nos recuerda que "sólo podrán ser sancionadas por hechos constitutivos de infracción administrativa las personas físicas y jurídicas que resulten responsables de los mismos aún a título de simple inobservancia". En consecuencia, no sólo podrán ser declarados responsables de una acción u omisión constitutiva de infracción las personas físicas, sino también las personas jurídicas ${ }^{41}$. Además, esa acción u omisión constitutiva de infracción ha de poderle ser imputada o atribuida (principio de culpabilidad) bien a título de dolo o bien a título de culpa, simple inobservancia dice la Ley.

40 Art. 317 RDPH.

41 Al contrario que en el Derecho Penal, en el Derecho Administrativo sancionador la responsabilidad directa de la persona jurídica ha sido y es un principio generalmente admitido tanto por la doctrina como por la jurisprudencia (ver, por ejemplo, la STC de 19 de diciembre de 1991). En la doctrina, sobre la 510 jurídica en el ámbito sancionador administrativo; RAP, núm. 129, septiembre-diciembre, 1992, pp. 211 a 239. 
Además, como dispone el RDPH, “los cómplices y encubridores podrán ser sancionados con multas que oscilarán entre el tercio y los dos tercios de las que correspondan a los autores de la infracción"42.

\section{Sanciones}

Como nos recuerda debidamente la LRJPAC, "únicamente por la comisión de infracciones administrativas podrán imponerse sanciones que, en todo caso, estarán delimitadas por la Ley" ${ }^{43}$, debiendo observarse el principio de proporcionalidad, es decir, que "en la imposición de sanciones por las Administraciones Públicas se deberá guardar la debida adecuación entre la gravedad del hecho constitutivo de la infracción y la sanción aplicada"44.

Observando tales principios, el TRLA prevé el siguiente esquema sancionador ${ }^{45}$, estando facultado el Gobierno para que, mediante Decreto, proceda a actualizar el importe de las sanciones ${ }^{46}$ que, a continuación, se exponen:

- Las infracciones leves, serán sancionadas con multa de hasta 6.010,12 euros $^{47}$.

- Las infracciones menos graves, se sancionarán con multa de 6.010,13 a $30.050,61$ euros $^{48}$.

42 Art. 318.2 RDPH.

43 Art. 129 LRJPAC.

44 Art. 131 LRJPAC.

45 Ver arts. 117.1 y 118 del TRLA.

46 Art. 117.3 del TRLA.

47 Además, según los apartados 2 y 3 del art. 319. del RDPH: "2. Podrán sancionarse con multa de hasta 240,40 euros las infracciones leves del artículo 315 contempladas en sus apartados c), d) y e), siempre que no se derivaran de ellas daños para los bienes del dominio público hidráulico, así como las previstas en los apartados b), f), g), h), i) y j) del citado artículo; y, 3. Podrán corresponder multas de hasta 450,76 euros a las infracciones tipificadas en los apartados a), c), d) y e) del mismo artículo cuando, de producirse daños para el dominio público hidráulico, éstos no superen los 450,76 euros. La sanción de este supuesto podrá alcanzar el duplo del importe de los mismos hasta un máximo de 901,52 euros".

48 Hay que completar estas sanciones con lo dispuesto en el art. 320 del RDPH. Según dicho precepto: "1. Podrán sancionarse con multa de hasta 1.803,04 euros las infracciones menos graves del artículo 316 contenidas en sus apartados a), d), e), f) y g), cuando se derivaran daños para el dominio público hidráulico superiores a 450,76 euros y no sobrepasaran los 901,52 euros. La sanción que corresponda a esos casos ascenderá al duplo del importe de los daños producidos. 2. Podrán corresponder multas de hasta 4.507,59 euros a las infracciones contempladas en los apartados b) y c) del citado artículo 316, así como a las enumeradas en el apartado anterior, siempre que en estos supuestos los daños ocasionados al dominio público hidráulico estuvieran comprendidos entre 901,53 y 2.253,80 euros, pudiendo sancionarse en este último supuesto la infracción con multa equivalente al duplo del valor del daño producido. 3. En los casos en que de las infracciones contempladas en el artículo 316 se derivaran daños para el dominio público hidráulico superiores a 2.253,80 euros, la sanción podrá ascender al triple del daño producido hasta un máximo de 9.015, 18 euros".

Y para la valoración de lo daños al dominio público hidráulico habrá que atenerse a lo dispuesto en el artículo 326 RDPH. Según dicho precepto: “1. La valoración de los daños al dominio público hidráulico se 
- Las infracciones graves, con multa de 30.052,62 a 300.506,06 euros.

— Las infracciones muy graves, con multa de 300.506,06 a 601.012,10 euros.

Surge aquí un problema, pues al poner en contacto la redacción del artículo 117 TRLA con la de los artículos 318 a 321 del RDPH surge una evidente contradicción. Así es, el art. 117 TRLA reproduce el texto del anterior artículo 109.1 de la Ley 29/1985, de 2 de agosto, de Aguas, de conformidad con la modificación introducida por la Disposición Adicional Novena, Apartado 2. ${ }^{\circ}$ de la Ley 42/1994, de 30 de diciembre, de medidas fiscales, administrativas y del orden social, que no hizo otra cosa que elevar las cuantías de las sanciones previstas en la redacción original del aludido artículo 109.1.

Pero el RDPH, por una parte, califica, por mandato legal, las infracciones que aparecen tipificadas en el TRLA como leves, menos graves, graves y muy graves, y, por otra, en los artículos 317 a 320 procede a graduar, señalando sus límites máximos y mínimos, las sanciones que deben imponerse por la comisión de cada tipo de infracción. El problema reside en que tanto para la clasificación de las infracciones como para la graduación de las sanciones el RDPH prevé unos límites cuantitativos que, por la fecha en que fue promulgado, se correspondían con las cuantías de las multas contempladas en la redacción originaria del artículo 109.1 de la Ley 29/1985, pero no con la cuantía de las multas que fueron ya modificadas por virtud de la Ley 42/1994, que son las que ya actualmente sí recoge el artículo 117 del TRLA. Aunque con posterioridad a la promulgación del TRLA el RDPH ha sufrido algunas modificaciones posteriores, fundamentalmente a través de la Resolución de 21 de noviembre de $200 \mathrm{l}$ del Ministerio de Medio Ambiente ${ }^{49}$, que han logrado subsanar parcialmente la descoordinación existente entre los preceptos de aquél y de éste, debe advertirse que la modificación que sufrió el original artículo 109.1 de la Ley de Aguas por la Ley 42/1994 y que se incorporó al actual TRLA a través del actual artículo 117 no se ha visto acompañada por la necesaria modificación o adecuación del Capítulo I del Título V del RDPH ni en lo que respecta a la tipificación de las infracciones en sus diversas categorías ni en lo que se refiere a la graduación de las sanciones pertinentes. Por ello, la cuestión que se plantea es si deben aplicarse los límites cuantitativos previstos en los artículos 319 y 320 del RDPH para la determinación de las correspondientes sanciones a imponer a consecuencia de la comisión de ciertas infracciones leves y menos graves en

realizará por el órgano sancionador. A tal efecto y sin perjuicio de las competencias de las Juntas de Gobierno, el Ministro de Medio Ambiente y Medio Rural y Marino establecerá los criterios técnicos para su determinación. 2. Si los daños se hubiesen producido en la calidad del agua, para su valoración se atenderá al coste del tratamiento del vertido, a su peligrosidad y a la sensibilidad del medio receptor".

49 Por cierto, esta Resolución de 21 de noviembre de 2001 transformó a euros las cuantías de las sanciones. Estimando como dudosamente legal este proceder de la Administración, la Sentencia del Tribunal Superior de Justicia de Castilla La Mancha, de 27 de octubre de 2006, señala que “En dicha resolución la Administración se arrogó el derecho de reformar -por cierto, por mera Resolución, de modo que la lega512 lidad de la actuación administrativa es sumamente dudosa- la redacción del artículo 318 del Real Decreto 849/1986, adaptándola a lo establecido en la Ley 42/1994...". 
función de los daños causados al dominio público hidráulico o, por el contrario, debe aplicarse las cuantías previstas en el artículo 117 del TRLA.

Pues bien, como han señalado la jurisprudencia ${ }^{50}$ y la doctrina $a^{51}$, los principios de legalidad y jerarquía normativa exigen ineludiblemente la aplicación de las cuantías previstas en el TRLA, las cuales no pueden quedar inobservadas, ser ineficaces por lo dispuesto en una norma reglamentaria. Por otro lado, de aceptarse la aplicación de estos preceptos reglamentarios se estarían alterando los límites de la sanción previstos en la Ley de Aguas, algo que viene expresamente prohibido por el artículo 129.3 de la LRJPAC, que define el principio de tipicidad en el ámbito del Derecho Administrativo sancionador. En efecto, el artículo 129.3 LRJPAC prevé las limitaciones de la norma reglamentaria en relación con su ley habilitante en los siguientes términos: "Las disposiciones reglamentarias de desarrollo podrán introducir especificaciones o graduaciones al cuadro de las infracciones o sanciones establecidas legalmente que, sin constituir nuevas infracciones o sanciones, ni alterar la naturaleza o límites de las que la Ley contempla contribuyan a la más correcta identificación de las conductas o a la más precisa determinación de las sanciones correspondientes”. Es decir, de ninguna manera una norma reglamentaria podrá alterar los límites de las sanciones previstos por la Ley ni mucho menos excluir su aplicación.

De conformidad con ello, los órganos competentes para el ejercicio de la potestad sancionadora deberán llevar a cabo la oportuna conversión de las cuantías establecidas por el RDPH en orden a la calificación de las infracciones como leves, menos graves, graves y muy graves (artículos 315, 316 y 317) y a la graduación de las sanciones pecuniarias (artículos 319 y 320) en las que resulten procedentes. Para ello, dada la vinculación existente entre las cuantías fijadas en el RDPH para calificar las infracciones y las cuantías de las sanciones pecuniarias, al quedar determinadas éstas por referencia a aquéllas, la conversión habrá de efectuarse por razón de la proporción aritmética en que se encuentren las cuantías fijadas por el Reglamento para calificar las infracciones y graduar las sanciones en relación con las antiguas cuantías de las multas; y una vez hallada la mencionada proporción, ésta habrá de aplicarse sobre las nuevas cuantías de las multas fijadas por el artículo 117 TRLA52.

Por otra parte, de la regulación del TRLA se deduce que, con independencia y sin perjuicio de la imposición de las multas, el órgano competente para el ejercicio de la

50 Sentencias del Tribunal Superior de Justicia de Cataluña de 6 de junio de 2002; del Tribunal Superior de Justicia de Castilla y León, Sala de Burgos, de 5 de mayo de 2006 y del Tribunal Superior de Justicia de la Región de Murcia de 17 de abril de 2006.

51 Guinot Barona, M. ${ }^{\text {a: }}$ Procedimientos sancionadores en materia de aguas: algunas cuestiones controvertidas; Actualidad Administrativa, La Ley, 3737/2009, 6, Quincena del 16 al 31 de marzo de 2009, Tomo I, pp. 14 a 18.

52 Así se deduce del Dictamen del Servicio Jurídico del Estado núm 16/95 (A.G. Servicios Jurídicos Periféricos). 
potestad sancionadora, podrá acordar e imponer al responsable de la infracción cometida las siguientes medidas accesorias ${ }^{53}$ :

— La obligación de reparar los daños y perjuicios ocasionados al dominio público hidráulico;

— La reposición de las cosas a su estado anterior.

Con ello, se pretende conseguir una doble finalidad ${ }^{54}$ :

- En primer lugar, obtener la reparación de los daños causados a los bienes públicos.

- En segundo lugar, de lo que realmente se trata no es tanto de proteger la titularidad de los bienes públicos sino de mantener su utilidad pública, su afectación, la conservación de las condiciones materiales que hacen posible esa utilidad.

En efecto, una de las potestades más importantes que, con respecto a los bienes de dominio público, puede ejercitar la Administración competente descansa en la posibilidad reconocida de que aquélla, por sí misma, fije el importe de la indemnización de los daños y perjuicios que la comisión de la infracción pertinente causen ${ }^{55}$.

En efecto, el régimen de reparación de daños en el dominio público hidráulico sigue un régimen de autotutela ejecutiva a favor de la Administración, derivado de la acumulación de dicha reparación en el expediente sancionador, siendo sobre los infractores sobre quienes recae la obligación de reparar el daño causado. En consecuencia, si no se produjera o constatara el daño el efecto inmediato sería la ausencia de tipicidad del hecho como infracción, con la debida declaración de nulidad de la sanción.

Evidentemente, "la Administración seguirá este régimen legal (de acumulación de reparación de daños y sanción) que le beneficia, al permitirle la ejecutoriedad inmediata de la reparación de daños con tal de que acumule ésta en el expediente sancionador. Paradójico es que, con todo ello, la legislación esté motivando la apertura de procedimientos sancionadores, ya que, aun cuando el interés de la Administración no sea más que la reparación del daño, aquélla decretará la apertura de un expediente sancionador, con el fin de seguir el cómodo sistema de autotutela ejecutiva y de evitar la interposición de las acciones civiles -ante los Tribunales- para lograr la reparación del daño" ${ }^{56}$.

53 Art. 118 TRLA y 323 del RDPH.

54 Sobre ello, ver Calvo del Pozo, J.: Potestad sancionadora e indemnización de daños y perjuicios al dominio público; RAAP, núm. 40, octubre-diciembre 2000, p. 268.

55 Art. 118.1 in fine TRLA.

56 González-Varas Ibáñez, S.: Autotutela y control judicial: ¿una sentencia innovadora en cuanto a

514 las sanciones y la reparación de daños?; REDA, núm. 99, julio-septiembre 1998, pp. 408 y 409. 
Ha de advertirse, pues, que la indemnización de los daños y perjuicios que derivan de la infracción cometida aparece vinculada a la potestad administrativa sancionadora. Ahora bien, la regulación conjunta, en el ámbito de las infracciones y sanciones, de las cuestiones de reparación y restitución, por una parte, y de la indemnización de daños y perjuicios, por otra, no excluyentes entre sí, no puede hacernos olvidar que estamos ante figuras de distinta naturaleza y autónomas, que tienen distinta finalidad ${ }^{57}$. La pregunta a plantear y resolver sería: ¿puede imponerse la indemnización si no hay sanción?

En este sentido, del hecho de que el TRLA y el RDPH utilicen la expresión "con independencia de las sanciones que sean impuestas" nos lleva a decantarnos por el carácter autónomo de la acción de reparación, sin que su ejercicio pueda quedar condicionado ni ser dependiente de la imposición efectiva de una sanción, obligación ésta que podrá exigirse en el plazo de quince años a tenor del artículo 327 del RDPH.

De hecho, nuestra jurisprudencia ${ }^{5}$ ha respaldado la distinción entre el plazo de prescripción de la infracción y el de la obligación de reparar el daño causado, señalando que el plazo de prescripción de la acción reconocida en el artículo 327.1 del RDPH Para que la Administración pueda exigir la reparación de los daños causados al dominio público hidráulico es el de quince años. Por ello, puede decirse que existe autonomía entre la acción de la acción de reparación de daños, y su prescripción, y la acción para sancionar las infracciones. Así aparece reconocido por la STS de 29 de noviembre de 2001 al expresar "la "independencia" de las sanciones a las que pueden ser condenados los infractores respecto de sus obligaciones de reparar los daños y perjuicios ocasionados al dominio público hidráulico y de reponer las cosas a su estado anterior, pronunciamientos estos dos últimos de carácter resarcitorio que la Administración puede fijar ejecutoriamente al margen de que se sancione o no a aquellos infractores". Al fin y al cabo estas obligaciones de reponer y reparar vienen a ser manifestaciones del principio quien contamina, paga que inspira el régimen de protección medioambiental en materia de aguas y otros recursos naturales, debiendo ser aplicado rigurosamente por nuestras Administraciones públicas para evitar la degradación de dichos recursos 59 .

57 Así se manifiestan Calvo del Pozo, J.: Potestad sancionadora e indemnización de daños y perjuicios al dominio público; RAAP, núm. 40, octubre-diciembre 2000, p. 302 y Guinot Barona, M.a: Procedimientos sancionadores en materia de aguas: algunas cuestiones controvertidas; Actualidad Administrativa, La Ley, 3737/2009, quincena del 16 al 31 de marzo de 2009, Tomo I, pp. 11.

58 Ver la STS de 24 de julio de 2003.

59 En sentido análogo, se manifiesta la STS de 2 de febrero de 2001.

A estos efectos, también resulta relevante la previsión de la Ley 26/2007, de 23 de octubre, de Responsabilidad Medioambiental, que fija el plazo de treinta años para que pueda exigirse la reparación de los daños medioambientales a contar desde que tuvo lugar la emisión, el suceso o el incidente que los causó. Ahora bien, esta norma no se extiende a todos los daños causados al dominio público hidráulico, sino sólo a los que tengan la consideración legal de daños medioambientales; y tampoco alcanza a cualquier sujeto responsable, sino exclusivamente a aquellos operadores que realicen alguna de las actividades económicas o profesionales previstas en su Anexo III, de entre las que destaca la de vertidos. 
En conclusión, "no cabe duda ninguna de la posibilidad de imponer la obligación de indemnizar los daños y perjuicios ocasionados en los supuestos en los que la infracción haya prescrito, pudiendo declararse tal obligación en la Resolución que ponga fin al procedimiento sancionador apreciando de oficio la prescripción de la acción punitiva, sin necesidad de incoar nuevo pronunciamiento al efecto" ${ }^{60}$.

Supuesto distinto sería que estuviéramos en un procedimiento sancionador que ha sido declarado caducado por la propia Administración, pues en este caso no puede válidamente ordenarse por la Administración la reparación del daño causado. Así es, una vez que se produce la caducidad del expediente sancionador no puede hacerse efectiva la orden de reparación del daño causado en el dominio público hidráulico ${ }^{61}$. Aunque, como señala el artículo 92.3 LRJPAC, la caducidad no producirá por sí sola la prescripción de las acciones del particular o de la Administración, si bien los procedimientos caducados no interrumpirán el plazo de prescripción. En este sentido, la declaración de caducidad y archivo de las actuaciones establecidas para procedimientos en que las Administraciones públicas ejerciten potestades sancionadoras, vía artículo 44.2 LRJPAC no extinguen la acción de la Administración para ejercitar las potestades aludidas en dicho precepto, siéndoles de aplicación lo previsto en el artículo 92.3 LR$J_{P A C}{ }^{62}$. En otras palabras "la caducidad del procedimiento sancionador cuyo objeto es determinar si se ha cometido una infracción contra el dominio público hidráulico y, en su caso, fijar la indemnización correspondiente por los daños causados a este demanio natural, desde luego no comporta la prescripción de la acción para exigir la reparación de los daños causados al dominio público, si bien tampoco producirá la interrupción del plazo prescriptito, ex artículo 92.3 de la LRJPAC"63. Y, además, nada impide que la Administración incoe un nuevo expediente para reclamar la responsabilidad por el daño ocasionado siempre que no haya prescrito la acción.

Pues bien, tanto el importe de las sanciones como el de las responsabilidades a que pudiera haber lugar, pueden ser exigidos por la vía administrativa de apremio ${ }^{64}, \mathrm{y}$, además, los órganos sancionadores están facultados para imponer multas coercitivas en los supuestos contemplados en la LRJPAC, si bien la cuantía de cada multa no podrá superar nunca el 10 por 100 de la sanción máxima fijada para la infracción cometida ${ }^{65}$.

60 Guinot Barona, M. a: Procedimientos sancionadores en materia de aguas: algunas cuestiones controvertidas; Actualidad Administrativa, La Ley, 3737/2009, quincena del 16 al 31 de marzo de 2009, Tomo I, pp. 12.

61 Ver art. 44.2 de la LRJPAC.

62 Como señala la STSJ de Castilla La Mancha de 23 de julio de 1999, la caducidad sólo despliega sus efectos sobre el expediente mismo, sin que llegue a afectar al substrato material al que se refiere, de modo que, siempre que no esté prescrita la infracción cabe la apertura de un nuevo expediente.

Por otro lado, no opera la caducidad de los expedientes cuando la demora de los mismos sea debida a incumplimientos de plazos o a dilaciones imputables al presunto infractor, tal y como declara la STSJ de la Comunidad de Madrid de 12 de diciembre de 2003.

63 Guinot Barona, M. a: Procedimientos sancionadores en materia de aguas: algunas cuestiones controvertidas; Actualidad Administrativa, La Ley, 3737/2009, quincena del 16 al 31 de marzo de 2009, Tomo I, pp. 13.

$516 \quad 64$ Art. 118.2 TRLA. 
Eso sí, será necesario que con anterioridad a la imposición de la multa coercitiva se haya apercibido al infractor, fijándose en éste un plazo para que aquél proceda a la ejecución voluntaria de lo ordenado, plazo que será fijado por el organismo sancionador en función de las circunstancias concretas de cada caso ${ }^{66}$. Lo cierto es que esta remisión genérica a los supuestos de la LRJPAC para la posible imposición de multas coercitivas no ha sido bien acogida por la doctrina ${ }^{67}$ que exige el que fuera la propia Ley de Aguas la que debió prever los casos o actos para cuya ejecución hubiera podido utilizarse la multa coercitiva. Al no ser así, deberá interpretarse que en la ejecución de todos los actos administrativos que puedan dictarse en aplicación del TRLA puede utilizarse la multa coercitiva siempre que se dé alguno de los supuestos de la LRJPAC ${ }^{68}$.

Además, los órganos sancionadores, con el fin de garantizar la eficacia de la resolución final que pudiera recaer podrán adoptar, provisionalmente, todas aquellas medidas cautelares que resulten necesarias para evitar la continuación de la actividad infractora, tales como el sellado de las instalaciones, aparatos, equipos y pozos, así como el cese de las correspondientes actividades ${ }^{69}$.

$\mathrm{Y}$, ¿a quién compete la potestad de sancionar las infracciones que se cometan contra el dominio público hidráulico? Pues bien, dependiendo del ilícito cometido, la competencia para imponer sanciones en este ámbito corresponde, según el TRLA ${ }^{70}$ :

- Cuando estemos en presencia de infracciones leves y menos graves, la competencia le corresponde a los Organismos de cuenca (confederaciones hidrográficas).

- Si estuviéramos ante infracciones graves el órgano competente es el Ministro de Medio Ambiente y Medio Rural y Marino. Dentro de este Ministerio, las funciones relacionadas con la protección del dominio público hidráulico están atribuidas a la Dirección General del Agua, dependiente de la Secretaría de Estado de Medio Rural y Marino ${ }^{71}$.

- Y si fueran infracciones muy graves, la competencia para sancionarlas recae en el Consejo de Ministros. En efecto, como órgano colegiado supremo de la Administración General del Estado tiene reservado el ejercicio de la potestad sancionadora para los ilícitos calificados como muy graves, con independencia de su facultad para revisar, mediante reglamento, las cuantías fijadas para las multas.

66 Art. 324.2 RDPH.

67 González Pérez, J.: Comentarios a la Ley de Aguas, Civitas, Madrid, 1987, p. 1095.

68 Aristóteles, J. M.a y Perales Magan, en la voz: Régimen de infracciones y sanciones, del libro dirigido por Embid Irujo, A.: Diccionario de Derecho de Aguas, lustel, 2007, p. 806.

69 Art. 119.2 TRLA.

70 Art. 117.2 TRLA.

71 En virtud del Real Decreto 438/2008, de 12 de abril. 
Hay que decir, también, que las Comunidades de Usuarios ${ }^{72}$, como corporaciones de derecho público adscritas al organismo de cuenca, gozan, en los procedimientos sancionadores, de un papel especial al quedar obligadas preceptivamente a denunciar a dicho organismo, la comisión de cualquier infracción en esta materia, si bien dichos ilícitos han de ser debidamente probados por ellas ${ }^{73}$.

Para concluir, de la regulación del TRLA se deduce que la protección del dominio público hidráulico aparece muy ligada a la consecución de sus objetivos medioambientales y no tanto en la protección del recurso en sí mismo considerado frente a las posibles infracciones de los particulares ${ }^{74}$. Así se deduce de los objetivos de protección del dominio público hidráulico fijados en sus artículos 92 y 92 bis: la prevención de su deterioro y de los ecosistemas acuáticos, terrestres y humedales que dependan de forma directa de los acuáticos; la promoción del uso sostenible del agua; la protección y mejora del medio acuático estableciendo medidas que reduzcan progresivamente los vertidos, emisiones y pérdidas de sustancias prioritarias; el garantizar la reducción progresiva de la contaminación; etc. En efecto, si bien no puede desconocerse o dejar de reconocerse que tanto todo el complejo entramado de la Administración hidráulica, como las diversas técnicas de las autorizaciones y concesiones o el propio Registro de Aguas sirven o tienen como finalidad, también, la protección del recurso, lo cierto es que la protección del demanio público hidráulico tiene un marcado sesgo medioambiental como queda reflejado en las prohibiciones contenidas en el artículo 97 TRLA (la acumulación de residuos que contaminen o puedan contaminar las aguas o degraden su entorno; las acciones sobre el medio físico o biológico que constituyan o puedan constituir una degradación del mismo; las actividades dentro de los perímetros de protección que puedan constituir un peligro de contaminación o degradación del demanio hídrico), en la exigencia de llevar a cabo estudios de impacto ambiental respecto de todas aquellas autorizaciones o concesiones que impliquen o puedan implicar un riesgo para el medio ambiente (artículo 98 TRLA) y, como no, con las autorizaciones de vertidos previstas en el artículo 94 TRLA.

\section{Prescripción de infracciones y sanciones}

En esta materia, el RDPH ${ }^{75}$ se remite, tras la redacción dada al mismo por el Real Decreto 1771/1994, de 5 de agosto, a la LRJPAC disponiendo específicamente que la acción para sancionar las infracciones previstas en el mismo prescribirá en los plazos establecidos en el artículo 132 de la Ley 30/1992.

En este sentido, la LRJPAC señala en dicho precepto, en su apartado primero, que "las infracciones y sanciones prescribirán según lo dispuesto en las leyes que las

72 Reguladas en los arts. 19 y 20 del TRLA.

73 Sentencia del Tribunal Superior de Justicia de La Rioja de 12 de diciembre de 1996.

74 Así opinan también Aristóteles, J. M. ${ }^{a}$, y Perales Magan, en la voz: Régimen de infracciones y sanciones, del libro dirigido por Embid Irujo, A.: Diccionario de Derecho de Aguas, lustel, 2007, p. 797.

75 Art. $327 \mathrm{RDPH}$. 
establezcan. Si éstas no fijan plazos de prescripción, las infracciones muy graves prescribirán a los tres años, las graves a los dos años y las leves a los seis meses".

En realidad, esta remisión en bloque a la LRJPAC no hace otra cosa que complicar la cuestión pues no podemos olvidar que tanto el TRLA como su RDPH realizan una clasificación de las infracciones distinguiendo hasta cuatro clases o tipos de las mismas: a saber, leves, menos graves, graves y muy graves, mientras que la LRJPAC sólo contiene una clasificación de las infracciones tripartita: leves, graves y muy graves. Evidentemente, el problema se sitúa en las infracciones menos graves a las que no se alude en la LRJPAC. Entonces, la pregunta es obvia: ¿qué plazo de prescripción hay que aplicar a las mismas? La respuesta, al estar en el ámbito del Derecho Sancionador, es clara también pues como sabemos éste debe de interpretarse de la forma más favorable para el posible infractor, lo que obliga a asemejar las infracciones menos graves con la leves y a concluir que el plazo prescriptito para las mismas ha de ser el de seis meses que se prevé para este tipo de infracciones leves en el artículo 132.1 LRJPAC $^{76}$.

La prescripción de la infracción deja abierta, no obstante, y, en su caso, la posible exigencia o depuración de la responsabilidad civil, pues la obligación de reponer las cosas a su estado primitivo o de reparar los daños causados al dominio público prescribe a los quince años ${ }^{77}$. Así es, pues, como sabemos, la reparación e indemnización de los daños es independiente del procedimiento sancionador. También la jurisprudencia se ha pronunciado a favor de que el plazo de prescripción de la acción reconocida en el artículo 327.1 RDPH para que la Administración exija la reparación del daño causado al dominio público hidráulico sea el de quince años ${ }^{78}$. En consecuencia, dicho precepto distingue entre el plazo de prescripción de la acción para sancionar, remitiéndose para ello a la LRJPAC, y el de la obligación de reponer las cosas a su estado primitivo o de reparar los daños causados al dominio público hidráulico.

La institución de la prescripción debe apreciarse, de oficio, por la Administración o, en su caso, por los tribunales de justicia, aunque la concurrencia de la misma no haya sido alegada por la parte actora ${ }^{79}$.

La prescripción se interrumpe, como dispone el artículo 132.2 LRJPAC por la iniciación, con conocimiento del interesado, del procedimiento sancionador, razón por

76 En este sentido, Aristóteles, J. M. a, y Perales Magan, en la voz: Régimen de infracciones y sanciones, del libro dirigido por Embid Irujo, A.: Diccionario de Derecho de Aguas, lustel, 2007, p. 807 y Guinot Barona, M.a: Procedimientos sancionadores en materia de aguas: algunas cuestiones controvertidas; Actualidad Administrativa, La Ley, 3737/2009, quincena del 16 al 31 de marzo de 2009, Tomo I, p. 7. También la jurisprudencia se ha manifestado en este sentido. Ver, entre otras, las Sentencias del Tribunal Superior de Justicia de Andalucía de 28 de enero de 2000 o la del Tribunal Superior de Justicia de Extremadura de 13 de febrero de 2003.

77 Art. $327 \mathrm{RDPH}$.

78 Así, la STS de 24 de julio de 2003.

79 Así lo señala la Sentencia del Tribunal Superior de Justicia de Castilla y León, de 7 de febrero de 2003. 
la que la notificación del acto de iniciación adquiere un significado jurídico capital pues es el que va revestido de esa naturaleza interruptiva. Dicho plazo se reanudará en el caso de que el expediente sancionador esté paralizado durante más de un mes por causa no imputable al presunto responsable ${ }^{80}$. Y teniendo presente que no interrumpirán el plazo de prescripción ni las posibles actuaciones previas que se realicen conforme a lo previsto en los artículos 69 LRJPAC y 12 del REPS, que son previos al expediente sancionador no formando parte del mismo, ni, asimismo, la denuncia practicada por los Agentes del Servicio de Protección de la Naturaleza o por los Servicios de Guardería Fluvial del Organismo de cuenca prevista en los artículos 328 y 329 RPDH y el artículo 11 del RPES ${ }^{81}$.

Y cuándo empieza a correr el plazo de prescripción. A falta de pronunciamiento expreso en el TRLA y en el RDPH, habrá que estarse a lo dispuesto en el artículo 132.2 LRJPAC cuando señala que el mismo comenzará a contar desde el día en que la infracción se hubiera cometido. Y como ha señalado nuestra jurisprudencia ${ }^{82}$, cuando la conducta infractora traiga su causa de una acción de la que no haya constancia que la misma haya cesado, el plazo de prescripción no empezará a correr hasta que cese la actividad antijurídica, pues estamos ante una acción que se mantiene en el tiempo. Esta misma doctrina es aplicable tanto a los casos de infracciones continuadas, es decir, las que consisten en una pluralidad de acciones u omisiones, una reiteración de actos análogos de naturaleza ilícita, que conculcan un mismo o semejante precepto administrativo en ejecución de un plan preconcebido o aprovechando idéntica ocasión ${ }^{83}$, como cuando estemos ante un supuesto de infracción permanente o continua, que es la que exige una única acción, a diferencia de la anterior, cuyo inicio se sitúa en un determinado momento temporal, pero que aún continua consumándose paulatinamente a través de la comisión de la conducta tipificada, siendo posible incluso su agravación a consecuencia del transcurso de los años. Ahora bien, estos supuestos no pueden asimilarse ni equipararse a aquellos casos de una acción que se ejecuta de forma instantánea cuya consumación queda agotada por el mismo momento en que se realizan, pero que, sin embargo sus efectos continúan en el tiempo, presentando, por tanto, un carácter permanente.

\section{Procedimiento administrativo sancionador}

El ejercicio de la potestad sancionadora en garantía de la indemnidad y protección del dominio público hidráulico estatal se regula, en cuanto a su procedimiento,

80 Así lo proclama la Sentencia del Tribunal Superior de Justicia de Murcia de 24 de mayo de 2000.

81 Así opina también Guinot Barona, M.a: Procedimientos sancionadores en materia de aguas: algunas cuestiones controvertidas; Actualidad Administrativa, La Ley, 3737/2009, quincena del 16 al 31 de marzo de 2009, Tomo I, p. 7.

$\begin{array}{lll}520 & 82 & \text { STS de } 5 \text { de octubre de } 1990 . \\ & 83 & \text { Definición de infracción continuada prevista en el art. } 4.6 \text { del RPES. }\end{array}$ 
por el Reglamento del procedimiento para el ejercicio de la potestad sancionadora (RPES), con ciertas especialidades que se prevén en el RDPH ${ }^{84}$.

Con respecto a las infraccione leves ha de establecerse, de forma reglamentaria, un procedimiento abreviado y sumario, respetando los principios establecidos en la LRJPAC $^{85}$.

Siguiendo las distintas fases del procedimiento sancionador, destacaremos las siguientes peculiaridades en materia de aguas.

Por lo que respecta a la iniciación, el procedimiento se inicia de oficio ${ }^{86}$, por el Organismo de cuenca, bien a consecuencia de una orden superior o a través de una denuncia.

La denuncia puede formularse voluntariamente por cualquier persona física o jurídica. Ahora bien, en todo caso, resultan compelidos u obligados a practicar la denuncia:

- La Guardería Fluvial del Organismo de cuenca. Si la infracción fuera observada por el servicio de guardería fluvial, en este caso, el denunciante debe entregar al denunciado, si le fuera posible, un duplicado del parte de denuncia que se curse. Si no fuera posible dicha entrega se procederá, entonces, a dar curso al parte de denuncia.

- Los Agentes de la Autoridad. En este sentido, nuestra jurisprudencia ha venido declarando que los hechos constatados en las denuncias levantadas por los funcionarios y por los agentes de la autoridad gozan de presunción de veracidad y valor probatorio, lo que hace decaer la presunción constitucional de inexistencia de responsabilidad predicable de la persona imputada, sin perjuicio de que esos hechos puedan ser desvirtuados por otras pruebas ${ }^{87}$. En conclusión, "la presunción de vera-

84 Art. 327.2 RDPH. Sobre el procedimiento me remito a: Infracciones y Sanciones 2008-2009, Memento Práctico Francis Lefebvre, 2007, pp. 1475 y 1476 y Fernández García, J.F.: El régimen sancionador en materia de dominio público hidráulico, Capítulo 15, del libro coordinado por González-Varas Ibáñez, S: Nuevo Derecho de Aguas, Thomson-Civitas, 2007, pp. 527 a 540.

85 Art. 117.2 TRLA. Por otra parte, apostando por la implantación de procedimientos administrativos abreviados para el ámbito del procedimiento administrativo sancionador en general y no sólo para la represión de los ilícitos menores se manifiesta Lozano Cutanda, B.: Procedimientos abreviados para la represión de las infracciones administrativas: el pago voluntario en cuantía reducida; REDA, núm. 66, abriljunio 1990, pp. 221 a 254.

86 La doctrina mayoritaria se manifiesta a favor o en defensa del principio de oficialidad u obligatoriedad, sin excepciones, del ejercicio de la potestad sancionadora como consecuencia ineludible del principio de legalidad que rige la potestad sancionadora de la Administración. Como muestra, me remito a Lozano Cutanda, B.: El principio de oficialidad de la acción sancionadora administrativa y las condiciones necesarias para garantizar su efectividad; RAP, núm. 161, mayo-agosto 2003, pp. 83 a 122.

87 Entre otras, así se pronuncian la STS de 14 de septiembre de 1990 y las Sentencias del Tribunal Superior de Justicia de Extremadura de 25 de septiembre de 2003 y de 29 de abril de 2009, así como la Sentencia del Tribunal Superior de Justicia de Andalucía, con sede en Granada, de 29 de octubre de 2007. 
cidad de una denuncia suscrita por un Agente de la Autoridad, dependerá de que los hechos reflejados en la misma hayan sido directamente constatados por aquél y que se acompañen todos los elementos probatorios existentes, por cuanto el conocimiento concreto de estos elementos es fundamental para el particular sujeto a una medida sancionadora para poder articular su derecho a la defensa con igualdad de armas" 88 .

- Los funcionarios que tengan encomendadas la inspección y vigilancia de las aguas u obras públicas.

- Las Comunidades de Usuarios u órganos con competencia similar, cuando se cometan infracciones que afecten a las aguas por ellos administradas.

- Cuantos funcionarios o empleados presten servicios de guardería, inspección o análogos, en canales, embalses o acequias de aguas públicas o derivadas en su origen de cauces de dominio público.

Si la denuncia se presentara por cualquier particular, el mismo ha de cursar la denuncia, verbalmente o por escrito, ante cualquiera de las autoridades anteriormente señaladas o, en su caso, directamente al Organismo de Cuenca.

Pues bien, el acuerdo que permite la iniciación de oficio del expediente sancionador, necesariamente contendrá los siguientes requisitos:

1. La formulación del pliego de cargos, que le será notificado al presunto infractor concediéndosele un plazo de 10 días hábiles para que formule sus alegaciones y proponga las pruebas que a su derecho convengan. En la notificación se deberán hacer constar, a mayores, los preceptos que se han infringido, los daños que se han originado y las sanciones procedentes.

2. La adopción de las medidas cautelares que procedan para asegurar la eficacia de la resolución final que pudiera recaer y que se estimen necesarias para evitar la continuación de la actividad infractora, como pueden ser, el sellado de las instalaciones, aparatos, equipos y pozos así como el cese de las actividades ilegales (artículo 119 TRLA).

3. La designación de un instructor, que será el encargado de formular el pliego de cargos en los términos anteriormente descritos.

En el supuesto caso de que en el acto de iniciación del expediente, o bien posteriormente, en el curso de su instrucción resultara que las infracciones revistieran las

88 Así se pronuncia la Sentencia del Tribunal Superior de Justicia de Extremadura de 9 de junio de 2006. 
características propias constitutivas de delito o falta, la Administración está obligada a pasar el tanto de culpa a la jurisdicción competente, absteniéndose de continuar el procedimiento sancionador mientras la autoridad judicial no se haya pronunciado. Evidentemente, la sanción de la autoridad judicial excluye la posible imposición de multa administrativa. Ahora bien, si no se estimara la presencia de delito o falta, la Administración está facultada para continuar el expediente sancionador, eso sí, ciñéndose a los hechos que los tribunales hayan sido declarados probados.

En cuanto a la fase instructora ${ }^{89}$, será el Organismo de cuenca el que, una vez haya iniciado el expediente sancionador, acuerde, bien de oficio o bien a instancia de parte, la práctica de las pruebas que estime pertinentes y que tengan por fin tanto el oportuno esclarecimiento de los hechos como la determinación de las responsabilidades susceptibles de sanción, debiendo, asimismo, fijar el plazo que estime conveniente de acuerdo con la naturaleza de la prueba o pruebas a practicar.

Este organismo está facultado para recabar, a propuesta del instructor, cuantos informes estime necesarios, bien de otros organismos, autoridades o agentes de la autoridad o bien de las comunidades de usuarios, los cuales deberán evacuarlos o remitirlos en el plazo de diez días ${ }^{90}$.

Después de que se hubiere contestado el pliego de cargos y, practicado, en su caso, las pruebas oportunas y se haya completado el expediente con las alegaciones y documentos que procedan y siempre, previa audiencia del interesado, el instructor formulará la propuesta de resolución.

Pues bien, dentro de esta fase de la instrucción, los Organismos de cuenca ostentan las siguientes potestades:

1. ${ }^{\text {a }} \quad$ Potestades de inspección. En su virtud, pueden tener acceso a propiedades privadas, salvo que constituyan domicilio particular de las personas, tanto para inspeccionar las obras e instalaciones de aprovechamientos de aguas o bienes de dominio público que estuvieran situadas en aquellas propiedades, como para hacer efectivas las resoluciones dictadas con motivo del procedimiento sancionador, como pueden ser las de ejecución de las medidas cautelares acordadas.

2. Además, podrán recabar la colaboración de los alcaldes y autoridades gubernativas de la provincia (delegados y subdelegados del gobierno hay que entender), estando los mismos obligados a prestar el auxilio y apoyo necesario.

Para terminar, una vez finalizada la instrucción ${ }^{91}$, el Organismo de cuenca dictará la resolución procedente o bien remitirá el expediente a la dirección general que co-

89 Arts. 331 a 333 y 335 RDPH.

90 Art. 83 LRJPAC.

91 Arts. 326, 332, 336, 339 y 340 RDPH. 
rresponda para su elevación al órgano que tenga atribuida la competencia. El plazo para resolver no podrá exceder de un año, contado a partir de la incoación del expediente. Una vez que se haya dictado la resolución, habrá de notificarse al responsable ${ }^{92}$, comunicándole, de igual forma, el plazo para hacerla efectiva.

La resolución sancionadora contendrá, necesariamente, y, en su caso, la valoración de los daños producidos al dominio público hidráulico. En caso de que proceda, podrá hacer algún pronunciamiento sobre otras posibles responsabilidades derivadas de la infracción cometida, debiendo, eso sí, fijar el plazo oportuno para que se hagan efectivas así como el señalamiento, si procede, de la fianza que ha de constituirse.

Y, en fin, el importe de las sanciones así como el resto de las obligaciones pecuniarias han de ingresarse en la cuenta especial habilitada al efecto en el Banco de España. Dicho importe habrá de destinarse a efectuar las reparaciones o inversiones que exija la mejora del dominio público hidráulico afectado y, siempre, a la restitución de éste a su estado primitivo.

\section{INFRACCIONES, SANCIONES, PRESCRIPCIÓN Y PROCEDIMIENTO ADMINISTRATIVO SANCIONADOR EN MATERIA DE MINAS}

Primordialmente, la regulación del ejercicio de la potestad sancionadora en materia minera se contiene en la Ley 22/1973, de 21 de julio (LMi, en adelante), por su parte, regula el ejercicio de la potestad sancionadora, a nivel estatal, para la protección del dominio público minero en su Título XIII, que lleva por rúbrica: "Competencia administrativa y sanciones”. Regulación, ésta, que se desarrolla en el Reglamento General para el Régimen de la Minería, aprobado por Real Decreto 2857/1978, de 25 de agosto (RGRM, en adelante) ${ }^{93}$. Y ello, sin olvidarnos del carácter supletorio que tiene la regulación prevista, en materia de infracciones y sanciones, en la LPAAPP. Analicemos, pues, su regulación:

\section{Infracciones}

La LMi contempla un catálogo de infracciones en el que lo que destaca es la protección del dominio público minero. Así es, el artículo 121 tipifica un cuadro de infrac-

92 Arts. 58 y 59 LRJPAC.

93 Como señala la STS de 16 de enero de 2007: “El principio de legalidad, referido no sólo al ámbito penal sino también al administrativo, aparece consagrado constitucionalmente en el art. 25.1de la Constitución, según el cual "nadie puede ser condenado o sancionado por acciones y omisiones que en el momento de producirse no constituyan delito, falta o infracción administrativa, según la legislación vigente en aquél momento"... El régimen sancionador en la normativa de minas se encuentra fundamentalmente contenido en los siguientes artículos: artículo 121.1 de la Ley 22/1973, artículo 147.1 del Reglamento, de 524 modo que la Ley de Minas y su Reglamento, aún cuando normas preconstitucionales, estaban ya sujetas a dicho principio y se aprobaron en la confianza y seguridad de su observancia...". 
ciones dirigidas a la protección de los posibles daños que se ocasionen al dominio público minero o bien a la explotación que se haga del mismo tanto en el caso de que se haga aquélla sin autorización como en el supuesto caso de que se realice rebasando los límites de esa autorización. Además, el Reglamento General para el Régimen de la Minería (RGRM, en adelante) realiza una remisión, en materia de infracciones, al catálogo de las mismas ya tipificadas en la LMi94.

En efecto, el aludido precepto de la LMi procede a la tipificación de las infracciones en materia de minas de la siguiente manera:

Se considera infracción muy grave la comisión de una infracción grave cuando se aprecien circunstancias de reincidencia o de riesgo muy grave para las personas o el medio ambiente.

Por su parte, considera infracciones graves cualquiera de las siguientes:

a) La realización de cualquier actividad de aprovechamiento de recursos regulados por la presente Ley sin su correspondiente autorización o concesión.

b) La intrusión de labores y la realización de aprovechamientos fuera del perímetro otorgado.

c) La no presentación del Plan de Labores en el plazo y con los contenidos reglamentarios.

d) La realización de actividades reguladas en esta Ley sin la Dirección Facultativa a que se refiere el artículo 117.

e) La inadecuada conservación y mantenimiento de las explotaciones e instalaciones si de ello puede resultar un riesgo grave para las personas o el medio ambiente.

f) El incumplimiento de las obligaciones incluidas en el Plan de Restauración sin la autorización sin la autorización del órgano que lo aprobó, incluyendo la obligación de constituir y mantener la garantía suficiente para su cumplimiento en la cuantía y plazo fijados.

g) Las que, suponiendo un incumplimiento en materia de seguridad minera, supongan un riesgo para las personas o el medio ambiente.

h) La comisión de una infracción leve cuando se aprecien circunstancias de reincidencia o de riesgo grave para las personas o el medio ambiente.

94 También es de la misma opinión Suárez Ferrín, M. ${ }^{a}$ A.: Infracciones y sanciones; op cit., p. 192. 
No hace alusión la LMi a los posibles responsables de las infracciones, con lo que habrá que estar a lo dispuesto en el artículo 130 LRJPAC, del que, como ya sabemos, se deduce que no sólo podrán ser responsables las personas físicas, sino también las personas jurídicas, debiendo recaer el tanto de culpa correspondiente en el infractor para que le sea imputable la acción o omisión correspondiente, es decir, la misma debe de haber sido ejecutada por aquél bien con dolo o bien negligentemente. Además, en caso de que la infracción hubiere sido cometida por varias personas, el artículo 130.2 LRJPAC nos recuerda que la regla será la de la solidaridad, o sea, que la responsabilidad será solidaria cuando el cumplimiento de las obligaciones previstas en una disposición legal corresponda a varias personas conjuntamente.

\section{Sanciones}

El artículo 129 y 131 LRJPAC nos recuerdan, respectivamente, el principio de legalidad y el de proporcionalidad en materia sancionadora, siendo estos principios cumplidos adecuadamente por la LMi en su artículo 121, apartado 4.

En efecto, de conformidad con dicho precepto, las infracciones a los preceptos de la Ley, sin perjuicio de la declaración de caducidad o suspensión de los trabajos cuando proceda, se sancionarán de la forma siguiente:

1. Las sanciones muy graves con multas de hasta un millón de euros.

2. Las sanciones graves con multas de hasta trescientos mil euros.

3. Las sanciones leves con multas de hasta treinta mil euros.

Pues bien, para la determinación de la cuantía de las sanciones, habrán de tenerse en cuenta, las circunstancias siguientes:

A) El peligro ocasionado a las personas o al medio ambiente;

B) La importancia del daño o deterioro causado;

C) El grado de participación y el beneficio obtenido;

D) La intencionalidad en la comisión de la infracción; y, por último,

E) La reincidencia, entendida como comisión en el plazo de un año de una in-

526 fracción del mismo tipo y calificación, resuelto por sentencia firme. 
Por su parte, las sanciones de multa, que se impondrán previa la instrucción del correspondiente expediente, podrán ser repetidas cuantas veces sea preciso por los motivos siguientes ${ }^{95}$ :

a) Que la persona, física o jurídica, a la que se hubiere impuesto la sanción dejara transcurrir el plazo que se le hubiera fijado, sin dar cumplimiento a lo ordenado

b) Que, aun habiendo cumplido con lo ordenado, infringiera el mismo precepto que motivó la anterior sanción, pudiendo aumentarse la cuantía, aunque sin sobrepasar el límite máximo prefijado.

En todo caso, los gastos que origine la ejecución subsidiaria por la Administración, en caso de que se llevara ésta a efecto, serán independientes de las multas y las cuantías que se hubieran impuesto.

Por otro lado, el Real Decreto 2994/1982, de 15 de octubre, señala en su artículo 7, apartado 1, que el incumplimiento del Plan de restauración conllevará la aplicación de las sanciones previstas en la legislación de minas, pudiendo acordarse la caducidad de la concesión de explotación o permiso de investigación, en caso de incumplimiento.

Además, no podemos olvidarnos que, tal y como reconoce el artículo 130, apartado segundo de la LRJPAC ${ }^{96}$, las responsabilidades administrativas que se deriven del procedimiento sancionador serán compatibles con la exigencia al infractor de la reposición de la situación alterada por el mismo a su estado originario, así como con la indemnización de daños y perjuicios que podrán ser determinados por el órgano competente, debiendo, en este caso, comunicarse al infractor para su satisfacción en el plazo que al efecto se determine, y quedando, de no hacerse así, expedita la vía judicial correspondiente.

En consecuencia, no hay una obligación para la determinación de la cuantía de la indemnización en el seno del propio procedimiento sancionador. O dicho en otras palabras, las obligaciones de reparación e indemnización podrán determinarse en un procedimiento separado, para el que será competente el mismo órgano sancionador, que se regirá por las disposiciones generales de la LRJPAC, y en el que, particularmente, deberá observarse todo lo relacionado con el derecho a la formulación de alegaciones y a la presentación de pruebas por parte de los responsables.

Hay que tener presente que tanto la reparación como la cuantía de la indemnización podrá exigirse, de forma ejecutoria, por la Administración competente siguiendo, para hacerlas efectivas, cualquiera de las formas previstas en el artículo 96 LRJPAC.

95 Art. 147.1 y 2 del RGRM.

96 Complementado, en este sentido, por los arts. 8 y 22 RPES. 

serán:

Y, por último, los órganos competentes para la imposición de las sanciones

- El Consejo de Ministros, para la imposición de las sanciones muy graves.

- El Ministro de Industria, Turismo y Comercio, la imposición de las sanciones graves; $y$, nes leves.

El Director General de Política Energética y Minas, la imposición de las sancio-

\section{Prescripción de infracciones y sanciones}

Como exige el principio de seguridad jurídica, la prescripción es uno de los motivos por los que se extingue la posible responsabilidad del infractor que opera como una sanción que recae sobre el titular del ejercicio de la potestad sancionadora al no haber hecho uso de la misma y no haber exigido la responsabilidad correspondiente, aunque haya surgido la conducta infractora, ya sea a través de la imposición de la pertinente sanción, lo que se conoce como prescripción de la infracción, o bien a través de la inejecución de la misma, es decir, la prescripción de la sanción.

Peculiar, en este sentido, es la regulación de la LMi en materia de prescripción de infracciones pues ha de entenderse que todas ellas, al no hacer la Ley entre las leves, graves o muy graves, prescribirán al cabo de dos años de su comisión.

Al igual que en materia de aguas, la prescripción de la infracción deja abierta, en su caso, la depuración de la responsabilidad civil, pues la obligación de reponer las cosas a su estado primitivo o de reparar los daños causados al dominio público prescribe a los quince años.

En lo que respecta a su cómputo, habrá que estarse a lo señalado en el artículo 132.2 LRJPAC, conforme al cual, el plazo de prescripción de las infracciones comenzará a contarse desde el día en que la infracción se hubiera cometido.

Para el caso de las infracciones continuadas, al igual que en el caso de las aguas, el plazo de prescripción de la infracción comenzará a computarse desde que la misma hubiere cesado o desde el último acto con el que la infracción se consuma ${ }^{97}$.

97 STS de 9 de febrero de 1983.

Por otra parte y, al objeto del establecimiento de las diferencias entre las distintas clases de infracción administrativa al efecto de la determinación el momento de su consumación y, a partir del mismo, precisar cuándo comienza a correr el plazo de prescripción del ilícito, me remito a De Palma Del Teso, Á.: Las infracciones administrativas continuadas, las infracciones permanentes, las infracciones de estado y 528 las infracciones de pluralidad de actos: distinción a efectos del cómputo del plazo de prescripción; REDA, 
En cualquier caso, interrumpe la prescripción la iniciación, con conocimiento del interesado, del procedimiento sancionador, reanudándose el plazo de prescripción si el expediente sancionador estuviera paralizado durante más de un mes por causa no imputable al presunto responsable ${ }^{98}$.

Además, nuestra jurisprudencia ha sentado la doctrina legal de que: "el límite para el ejercicio de la potestad sancionadora y para la prescripción de las infracciones, concluye con la resolución sancionadora y su consiguiente notificación, sin poder extender la misma a la vía de recurso ${ }^{99}$.

Ni la LMi ni el RGRM, sin embargo, hacen alusión a la prescripción de las sanciones (en estos casos, la inactividad de la Administración se produce a la hora de la ejecución de la sanción), debiendo estarse, en este caso, a lo dispuesto por la LRJPAC. Según su artículo 132.1, las sanciones impuestas por faltas muy graves prescribirán a los tres años, las impuestas por faltas graves a los dos años y las impuestas por faltas leves al año. En estos casos, el plazo de prescripción de las sanciones empezará a contarse desde el día siguiente a aquel en que adquiera firmeza la resolución por la que se impone la sanción ${ }^{100}$. Habrá que plantearse, pues, si esa firmeza hace referencia a la vía administrativa o a la judicial. La doctrina, con base en el artículo 138 LRJPAC, entiende que se está haciendo referencia a la firmeza en vía administrativa ${ }^{101}$. Por último, interrumpirá el plazo de la prescripción la iniciación, con conocimiento del interesado, del procedimiento de ejecución, volviendo a transcurrir el plazo si aquél está paralizado durante más de un mes por causa no imputable al infractor ${ }^{102}$.

\section{Procedimiento administrativo sancionador}

Al igual que sucedía en materia de aguas, el ejercicio de la potestad sancionadora para garantizar la indemnidad y protección del dominio público minero estatal se canaliza por los trámites previstos en la legislación del Estado.

En este sentido y, con respecto al procedimiento sancionador, la LMi únicamente dispone ${ }^{103}$ que los expedientes incoados con arreglo a la misma se instruirán ante la Delegación Provincial correspondiente del Ministerio de Industria. La resolución, en última instancia administrativa, corresponderá a la Dirección General de Minas, al Ministro de Industria, Turismo y Comercio o al Consejo de Ministros, según lo previsto en la misma Ley.

98 Art. 132.2 LRJPAC.

99 STS de 15 de diciembre de 2004.

100 Art. 132.3 LRJPAC.

101 En este sentido, ver Suárez Ferrín, M. ${ }^{a}$ A.: Infracciones y sanciones; op cit., p. 1368.

102 Art. 132.3 LRJPAC.

103 Art. 114.2 LMi. 
Habrá que estarse, por lo tanto, a las normas y principios (garantía de procedimiento, notificación de los hechos que se le imputen, de la identidad del instructor y de la autoridad competente para imponer la sanción, derecho a formular alegaciones y utilizar los medios de defensa oportunos, etc.) que, en materia de procedimiento, se establecen tanto en la LRJPAC ${ }^{104}$ como, fundamentalmente, a las previstas, en el RPES, en lo relativo a la iniciación ${ }^{105}$, instrucción (con la correspondiente práctica de prueba y la propuesta de resolución), y, finalmente, la resolución y su notificación ${ }^{106}$.

Eso sí, la intervención de los Tribunales de la jurisdicción ordinaria en cuestiones de índole civil o penal atribuidas a su competencia no interrumpirá la tramitación administrativa de los expedientes ${ }^{107}$. Eso sí, en todo caso, los hechos declarados probados por resolución judicial penal firme vinculan a los órganos administrativos respecto de los procedimientos sancionadores que sustancien ${ }^{108}$.

Y, como medida provisional, siempre que resulte necesaria para asegurar la resolución que pudiera recaer, evitar el mantenimiento de los efectos de la infracción y las exigencias de los intereses generales, se prevé la suspensión provisional de los trabajos en la forma, por las autoridades y con los requisitos previstos en la $L M i^{109}$ y en el RGRM ${ }^{110}$.

Por otra parte, un tema recurrente a estos efectos es si la caducidad de las concesiones mineras tiene o no naturaleza sancionadora. En este sentido, tal y como ha declarado la doctrina las normas que la legislación de minas prevé sobre la extinción de los distintos tipos de títulos mineros (concesión, especialmente) "contribuyen a la confusión existente en nuestro ordenamiento jurídico en torno al concepto de cadu-

104 Capítulo II del Título IX: arts. 134 a 138.

105 Respecto de la iniciación del procedimiento por las denuncias formuladas por Agentes de la Autoridad, nuestra jurisprudencia ha sentado la doctrina legal siguiente: "Cuando la denuncia sobre los hechos sancionados es formulada por un Agente de la Autoridad, encargado del Servicio, la presunción de veracidad y legalidad que acompaña a todo obrar de los órganos administrativos y de sus agentes es un principio que debe acatarse y defenderse, ya que constituye esencial garantía de una acción administrativa eficaz, sin que ello quiera decir, en coordinación con el principio constitucional de presunción de inocencia, que los hechos denunciados por un Agente se consideren intangibles, ya que la realidad de los mismos puede quedar desvirtuada mediante la adecuada prueba en contrario". STS de 14 de septiembre de 1990 y Sentencias del Tribunal Superior de Justicia de Andalucía, con sede en Granada, de 29 de octubre de 2007 y de 7 de abril de 2003 .

106 Capítulos II, III y IV del RPES: arts. 11 a 22.

107 Art. 141.1 RGRM.

En efecto, como señala la STS de 12 de mayo de 2007, respecto del principio "non bis in idem", “el citado principio no siempre impide la sanción de unos mismos hechos por autoridades de distinto orden, cuando ellos sean contemplados desde perspectivas diferentes, pues lo que sí se impide es que por autoridades del mismo orden y a través de procedimientos distintos se sancione repetidamente la misma conducta...".

108 Art. 7.3 RPES.

109 Art. 116 LMi.

Como nos recuerda categóricamente la Sentencia del Tribunal Superior de Justicia de Castilla y León, con sede en Valladolid, de 24 de enero de 2006,, “... Por lo demás, que únicamente la autoridad administrativa con competencias en materia de minería solo puede suspender las labores de aprovechamiento es una idea que sanciona el artículo 116 de la Ley 22/1973 de Minas...". 110 Art. 142 RRGM. 
cidad como mecanismo extintivo de la concesión"111 al incluir en el mismo todas las causas extintivas de la concesión minera. Aún así, lo importante es que la potestad para declarar extinguida la concesión minera es de obligatorio ejercicio por parte de la Administración. La pregunta que debemos hacernos es si esta potestad tiene naturaleza sancionadora o no. La más reciente jurisprudencia ${ }^{112}$ y la doctrina más actual ${ }^{113}$, sostiene que la extinción por incumplimiento no tiene naturaleza sancionadora, por lo que el ejercicio de la potestad no se halla sometido a las disposiciones legales reguladoras de la potestad sancionadora, sino a las específicas contenidas en el artículo 111 RGRM. Esta, también, parece que es la solución por la que ha optado el legislador en el artículo 121, apartado cuarto de la LMi"14, al señalar que "las infracciones a los preceptos de esta Ley, sin perjuicio de la declaración de caducidad o suspensión de los trabajos cuando ello proceda, se sancionarán en la forma siguiente...". En consecuencia, con la redacción de dicho precepto, entendemos que queda desligada la declaración de caducidad del título minero del ejercicio de la potestad sancionadora o, dicho en otras palabras, "el redactor del artículo 121 de la LMi, dándole una nueva dicción, se ha decantado por no considerar a la declaración de caducidad como expresión de la potestad sancionadora de la Administración, que es lo técnicamente correcto”"115.

Para finalizar, el procedimiento sancionador caducará al año de su iniciación ${ }^{116}$. Es decir, el plazo para resolver no podrá exceder de un año, contado a partir de la incoación del expediente. Transcurrido dicho plazo sin resolución, se produce la caducidad del expediente sancionador. Este plazo de caducidad ha de computarse desde el día en que se notifica la incoación de oficio del expediente sancionador hasta el día en que se haya dictado y notificado la resolución expresa sancionadora. Por último, el principal efecto de la caducidad es el archivo del expediente, pero esto no obsta para que la Administración pueda reiniciar otro distinto.

\section{BIBLOGRAFÍA}

Andrés Pérez, M. ${ }^{a}$ del Rocío: El principio de proporcionalidad en el procedimiento administrativo sancionador; Bosch, 2008.

Aristóteles, J. M. ${ }^{\text {a }}$ y Perales Magan, en la voz: Régimen de infracciones y sanciones, del libro dirigido por Embid Irujo, A.: Diccionario de Derecho de Aguas, lustel, 2007.

111 Quintana López, T.: Viejos y nuevos problema de la concesión minera, Revista Jurídica de Castilla y León, núm. 18, mayo 2009, pp. 58 y 59.

112 STS de 16 de noviembre de 2006, de 5 de mayo de 2009 y STJJ Islas Canarias -Sede en Las Palmas- de 15 de abril de 2005.

113 Quintana López, T.: Viejos y nuevos problema de la concesión minera, Revista Jurídica de Castilla y León, núm. 18, mayo 2009, pp. 61 y 62.

114 Cuya nueva redacción se debe a la Ley 12/2007, de 2 de julio.

115 Quintana López, T.: Viejos y nuevos problema de la concesión minera, Revista Jurídica de Castilla y León, núm. 18, mayo 2009, pp. 62 y 63.

116 Art. 121.8 LMi. 
Beltrán Aguirre, J.L.: La prescripción de las infracciones administrativas: Unificación de la doctrina jurisprudencial; REDA, núm. 73, enero-marzo 1992.

Calvo del Pozo, J.: Potestad sancionadora e indemnización de daños y perjuicios al dominio público; $R A A P$, núm. 40, octubre-diciembre 2000.

Cano Campos, T.: La analogía en el Derecho administrativo sancionador; REDA, núm. 113, enero-marzo 2002.

Cano Mata, A.: Nuevo entorno de las infracciones y sanciones administrativas tras la entrada en vigor de la Constitución; REDA, núm. 56, octubre-diciembre 1987.

De Palma del Teso, Á.: Las infracciones administrativas continuadas, las infracciones permanentes, las infracciones de estado y las infracciones de pluralidad de actos: distinción a efectos del cómputo del plazo de prescripción; REDA, núm. 112, octubre-diciembre 2001.

Díez-Picazo, L.M.a: Derecho Comunitario y medidas sancionadoras; REDA, núm. 78, abril-junio 1993, p. 264.

Eugenio de Arcenegui, I.: La protección del medio ambiente a la luz de la legislación minera del Estado y de la Ley 12/81, de 24 de diciembre, de la Generalidad de Cataluña; $R A P$, núms. 101102, vol. III, enero-diciembre 1983.

Esteve Pardo, J.: Sanciones Administrativas y potestad reglamentaria; REDA, núm. 49, enero-marzo, 1986.

Fernández García, J.F.: El régimen sancionador en materia de dominio público hidráulico, Capítulo 15, del libro coordinado por González-Varas Ibáñez, S: Nuevo Derecho de Aguas, Thomson-Civitas, 2007.

Font i Llovet, T.: La protección del dominio público en la formación del Derecho administrativo español: Potestad sancionadora y resarcimiento de daños; $R A P$, núm. 123, septiembre-diciembre 1990.

García de Enterría, E.: El problema jurídico de las sanciones administrativas, REDA, núm. 10, 1976.

García de Enterría, E., y Fernández, T.R., Curso de Derecho Administrativo, II, 11. ${ }^{\text {e edic., }}$ Thomson-Civitas, 2008.

García Gómez de Mercado, F.: Sanciones administrativas; garantías, derechos y recursos del presunto responsable, Comares, $2 .^{\text {a }}$ edic, 2004.

Gómez Tomillo, M.: Derecho Administrativo Sancionador. Parte General. Teoría General y Práctica del Derecho Penal Administrativo, Thomson-Aranzadi, 2008.

González Navarro, F.: El "BigBang” del procedimiento administrativo sancionador común; $R E D A$, núm. 78, abril-junio 1993.

González Pérez, J.: Comentarios a la Ley de Aguas, Civitas, Madrid, 1987, p. 1095.

González-Varas Ibáñez, S.: Autotutela y control judicial: ¿una sentencia innovadora en cuanto a las sanciones y la reparación de daños?; REDA, núm. 99, julio-septiembre 1998.

Guinot Barona, M.. : Procedimientos sancionadores en materia de aguas: algunas cuestiones controvertidas; Actualidad Administrativa, La Ley 3737/2009, 6, Quincena del 16 al 31 de marzo de 2009.

Infracciones y Sanciones 20082009, Memento Práctico Francis Lefebvre, 2007.

Junceda Moreno,, J.: ¿Una vuelta hacia la responsabilidad objetiva en Derecho administrativo sancionador?; REDA, núm. 86, abril-junio, 1995. 
Lozano Cutanda, B.: Procedimientos abreviados para la represión de las infracciones administrativas: el pago voluntario en cuantía reducida; $R E D A$, núm. 66, abril-junio 1990.

Lozano Cutanda, B.: La responsabilidad de la persona jurídica en el ámbito sancionador administrativo; $R A P$, núm. 129, septiembre-diciembre, 1992.

Lozano Cutanda, B.: El principio de oficialidad de la acción sancionadora administrativa y las condiciones necesarias para garantizar su efectividad; $R A P$, núm. 161, mayo-agosto 2003.

Martín-Retortillo Baquer, L.: Multas Administrativas; RAP, núm. 79, enero-abril, 1976. Mestre Delgado, J.F.: Potestad reglamentaria y principio de legalidad: las limitaciones constitucionales en materia sancionadora; REDA, núm. 57, enero-marzo 1988.

Nieto, A.: Derecho Administrativo Sancionador, 4. ${ }^{\text {a }}$ edic., Tecnos, 2005.

Palomar Olmeda, A.: La protección del Medio Ambiente en materia de aguas; RAP, núm. 110, mayo-agosto 1986.

Pemán Gavín, J.: La regulación de la potestad sancionadora de la Administración en la Ley 30/1992, de 26 de noviembre: notas sobre su tramitación parlamentaria; $R A P$; núm. 132, septiembre-diciembre 1993.

Quintana López, T.: Viejos y nuevos problema de la concesión minera, Revista Jurídica de Castilla y León, núm. 18, mayo 2009.

Quintero Olivares, G.: La autotutela, los límites al poder sancionador de la Administración Pública y los principios inspiradores del Derecho penal; $R A P$, núm. 126, septiembre-diciembre 1991.

Suárez Ferrín, M. ${ }^{a}$ A.: Infracciones y Sanciones; Capítulo I del Libro dirigido por De Fuentes Bardají, J.: Comentarios a la Ley de Patrimonio de las Administraciones Públicas; Abogacía General del Estado (Ministerio de Justicia) y Thomson-Aranzadi, 2008.

Suay Rincón, J.: El Derecho administrativo sancionador: perspectivas de reforma, $R A P$, núm. 109, enero-abril 1986. 
